\title{
A ECOLOGIA POLÍTICA DA COSTA FLUMINENSE: UM ESTUDO ETNOGRÁFICO LONGITUDINAL DA PESCA, TURISMO E DESENVOLVIMENTO INDUSTRIAL NA BAÍA DE SEPETIBA
}

\author{
Scott William Hoefle \\ Universidade Federal do Rio de Janeiro
}

Resumo

Uma abordagem da ecologia política crítica global é usada num estudo etnográfico longitudinal envolvendo décadas de pesquisa sobre mudança no relacionamento entre pesca, turismo e desenvolvimento urbanoindustrial na costa fluminense. A expansão de grandes projetos industriais e da área edificada da região metropolitana do Rio de Janeiro trouxe grandes transformações socioambientais que, ora criaram ameaças à pesca, ora abriram novas oportunidades multifuncionais e também introduziram atividades justapostas que não interferem com a vida da população local. À medida que os estoques pesqueiros diminuíam devido ao uso de métodos predatórios no setor empresarial e à crescente poluição urbano-industrial nas últimas décadas, a pequena pesca de baias e de lagunas entrou em declínio a leste e sudoeste da região metropolitana. $O$ turismo aumentou, mas contribuiu pouco para agregar valor aos modos de vida multifuncionais. Consequentemente, somente uma pequena parcela dos pescadores se beneficiou e permaneceu nas ilhas e restingas enquanto a grande maioria foi morar em bairros populares dos centros urbanos no continente.

Palavras-chave: Ecologia Política Crítica; capitalização e descapitalização da pesca; turismo praiano; degradação ambiental; modo de vida multifuncional; costa fluminense.

\begin{abstract}
A critical global political ecology perspective is used in a longitudinal ethnographic study involving decades of research on the changing relationship between fisher livelihoods, seashore tourism and urban-industrial development on the coast of Rio de Janeiro state. As large industrial projects expanded and the metropolitan area of Rio de Janeiro encroached on fishing communities, socio-environmental transformations created threats to fisher ways of life, opened new multifunctional opportunities and also introduced unrelated juxtaposed activities. As stocks fell due to overfishing and urban-industrial pollution over the last two decades, small-scale inshore fishing declined in the bay-lagoon systems located to the east and south-west of Rio de Janeiro. Tourism increased but proved to be a poor substitute for declining fishing activities because it and other new multi-functional activities rarely aggregated significant value to the livelihoods of local people. Consequently, only a small minority of fishers benefited and remained on the islands and sand spits while the great majority left for poor urban areas of the mainland.
\end{abstract}

Key words: Critical Poltical Ecology; capitalization and de-capitalization of fishing; seashore tourism; multifunctional livelihoods; environmental degradation; coastal Rio de Janeiro.

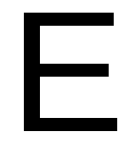

ste trabalho é tanto uma exposição teórica e metodológica quanto um estudo de caso empírico que trata uma região costeira do país. Primeiro, é apresentada a abordagem teórica da Ecologia Política Crítica que é utilizada para interpretar o relacionamento entre a pesca, o turismo e o desenvolvimento urbano-industrial na costa sul fluminense. Esta perspectiva tem am- 
pla difusão na geografia internacional, mas ainda é pouco conhecida no país. Em seguida, descreve a metodologia etnográfica longitudinal aplicada em múltiplos sítios de investigação, com atenção especial a considerações de objetividade científica num caso no qual o pesquisador também é um ator social local. O estudo de caso sobre as transformações socioespaciais ocorridas na costa sul fluminense é dividido em três períodos envolvendo a crescente penetração de interesses metropolitanos: 1) a fase antes de 1970 quando se praticavam a pesca artesanal de semisubsistência e o turismo de aventura, 2) a fase entre 1970 e 1990 durante o auge da pesca capitalizada de pequena escala e do turismo veterano e de elite e 3) a fase pós-1990 quando houve incorporação da área à região metropolitana, que causou a degradação ambiental, o declínio da pesca e o surgimento do turismo em massa.

\section{Teoria e métodos}

\section{Ecologia Política Crítica}

No stricto sensu a Ecologia Política é uma perspectiva teórica que foi inicialmente desenvolvida por geógrafos e antropólogos californianos e australianos em pesquisas realizadas em países menos desenvolvidos. Blaikie e Brookfield (1987) foram pioneiros na Geografia e Wolf (1982) na Antropologia, mas trabalhos semelhantes foram produzidos por Redclift (1987) na Sociologia, por Merchant (1992) na Ecologia e por Crosby (1986) na História Ambiental, de forma que a abordagem pode ser vista como um amplo movimento teórico nas Ciências Humanas. Como o nome sugere, a Ecologia Política foi resultado de uma síntese entre a Economia Política Neo-Marxista e a Ecologia Radical. Isso fica evidente na trajetória intelectual de Michael Redclift, que migrou de estudos marxistas sobre camponeses (GOODMAN, REDCLIFT, 1981) para estudos ambientais críticos (REDCLIFT, 1984), culminando em sua obra crítica da nova ortodoxia do desenvolvimento sustentável em 1987.

Do Neo-Marxismo a Ecologia Política incorporou uma abordagem global do ambiente dentro do sistema capitalista mundial, no qual existe acesso desigual aos recursos produtivos de acordo com a posição de classe social e a centralidade espacial do sistema. Do Ambientalismo Radical adotou uma ênfase em explicar degradação de recursos naturais em termos de pobreza, de criticar o industrialismo, uma visão do mundo caracterizada por grande diversidade ambiental e cultural e a ação política via movimentos sociais não-governamentais. A Ecologia Política também foi influenciada pelo Pós-estruturalismo e pelo Pós-modernismo sobre a sociedade fragmentada por diferentes identidades definidas por gênero, grupo étnico, grupo etário, afiliação religiosa e origem regional, que criam percepções conflitantes do ambiente bem como relações assimétricas do poder que provocam movimentos culturais de resistência.

Para Peet e Watts (2004), a Ecologia Política se tornou um paradigma científico no sentido de Kuhn (1962). Atraiu grande número de pesquisadores de vários campos do conhecimento, alcançando caráter transdisciplinar. Obras fundamentais foram produzidas por Blaikie e Brookfield, Hecht, Zimmerer, Rangan, Peluso, Davis, Schroeder, Durham e Neuman. Métodos, conceitos e problemas foram debatidos e reformulados induzindo renovação teórica e extensão para novas áreas de estudo. Pesquisa de campo foi realizada em todas as regiões do mundo. Existem revis- 
tas especializadas próprias: a Journal of Political Ecology e a Land Degradation and Rehabilitation. Livros texto foram produzidos para uso em cursos de graduação e pós-graduação. Nos anos de 1990 o Grupo de Estudo de Ecologia Política e Cultural da Associação Americana de Geógrafos chegou a ser o segundo maior, ficando atrás apenas do Grupo de Sistemas Geográficos de Informação, e metade dos membros eram alunos de pós-graduação. Hoje, a Ecologia Política também é aplicada em estudos sobre indústria e cidades em países pós-industriais (RADEMACHER, 2015; HUBER, 2017).

Os primeiros estudos geográficos e antropológicos da Ecologia Política foram criticados por serem curiosamente apolíticos, pelo uso de modelos ecológicos de equilíbrio, pelo foco excessivo em agricultura primitiva e por atrair pesquisadores predominantemente masculinos. Contudo, na virada do século novos métodos e modelos foram introduzidos. Observação participante passou a ser utilizada em uma gama de situações, desde o estudo de pobres rurais ao de ricos urbanos. Novos métodos foram incluídos, como por exemplo, a análise de discurso político de atores sociais situados em múltiplas escalas, a pesquisa em arquivos e a investigação sociológica de instituições complexas governamentais e não governamentais (COSGROVE, 1993; PEET, WATTS, 2004; PAULSON et al., 2003).

Durante as primeiras décadas do século XXI a Ecologia Política ficou cada vez mais radical num contexto mundial caracterizado por prolongada estagnação econômica, falta de progresso e mesmo recesso em acordos internacionais sobre o ambiente (apesar dos sinais alarmantes de mudanças climáticas), guerras regionais sobre fontes de energia e inação perante a crescente desigualdade social no mundo. Na atual Ecologia Política Crítica Global convergem abordagens marxistas e fenomenológicas sobre o ambiente que identificam contradições insuperáveis entre os sistemas agrícolas e industriais produtivistas e a preservação ecológica. Assim sendo, as inúmeras conferências globais sobre o ambiente são, na verdade, cortinas de fumaça que apenas simulam fazer algo para conter a escalada de degradação ambiental do planeta. As poucas políticas implementadas, como o mercado de carbono e a ajuda financeira para países pobres, são questionadas por ocultar o "colonialismo carbônico" e a "lavagem verde" de atividades insustentáveis e do estilo de vida dos maiores poluidores do planeta. Também são denunciadas políticas de conservação que são implimentadas às custas da população pobre do campo que perde seu modo de vida para dar lugar à Natureza (cf. HOEFLE, BICALHO, 2016; BÜSCHER, FLETCHER, 2018; DOWIE, 2009; FORSYTHE, 2003; HOEFLE, 2013; JACOBY, 2014; KELLY-REIF, WING, 2016; PEET et al., 2011; TAYLOR, 2015).

\section{Estudos geográficos sobre a pesca e o turismo}

A pesca não é um tópico comum na pesquisa geográfica e quando tratada é geralmente relacionada a questões ambientais e geopolíticas numa escala global, como por exemplo nos estudos de Mansfield (2011) e Nyman (2013). Assuntos como o impacto local do declínio de recursos pesqueiros, as relações de trabalho e de gênero no setor e a política comunitária são mais estudados por antropólogos e sociólogos. Através dos anos, foram publicados nessas disciplinas um grande número de artigos sobre pesca em diferentes partes do mundo na revista Human Organization, bem como resenhas, monografias e livros organizados, como por exemplo Anderson (1981), Wa- 
del (1972), Cole (1991,) Greenlaw (1999), Ingles (2007), McCay (2012), McGoodwin (1990), Smith (1977), Spoehr (1980) e Zulaika (1981). No país, o sociólogo Diegues (1983, 1991, 1996) é o maior especialista sobre a pesca e questões ambientais em zonas costeiras.

Já o turismo é bastante pesquisado por geógrafos que através dos anos fizeram importantes contribuições à literatura multidisciplinar sobre o assunto. Na segunda metade do século XX geógrafos construíram modelos quantitativos do transporte de turistas de origem urbana oriundos de países desenvolvidos para um "resort" de esqui na Europa ou na América do Norte ou para um "resort" praiano num país pobre (ex. PEARCE, 1981; SMITH, 1983). A publicação do livro The Tourist Gaze pelo sociólogo Urry em 1990 revolucionou o estudo de turismo. Em vez de enfatizar o papel do turismo para desenvolvimento econômico, questões ambientais e culturais passaram a ganhar importância. Como espetáculo, "performance" e diversidade cultural são centrais ao turismo, estudos nesta área assumiram um lugar importante na formulação de teoria social.

Hoje existem obras especializadas sobre uma gama de assuntos ambientais e culturais no turismo, tais como mudanças climáticas (BECKEN, HAY, 2008; SCOTT et al., 2012), ética animal (FENNELL, 2011), ecoturismo (BUCKLEY, 2008; CATER, CATER, 2007; EAGLES, McCOOL, 2000; STRONZA, DURHAM, 2008; ZEPPEL, 2006), gênero e corpo (PRITCHARD et al., 2007; WAITT, MARKWELL, 2006), sexo e prostituição (CLIFT, CARTER, 2000; RYAN, HALL, 2001), turismo voluntário (GARLAND, 2012; WEARING, 2001), bem como manuais especializados de pesquisa nestes tópicos (PIERCE, BUTLER, 1993; RAKIC, CHAMBERS, 2011; RICHARDS, MUNSTERS, 2010; RITCHIE et al., 2005).

\section{Etnografia longitudinal e 'objetivação' participante}

O presente estudo se baseia em contato pessoal com a baia de Sepetiba desde 1976, primeiro como turista veterano e depois como pesquisador. Por um lado, com mais de quarenta anos de contato com a área de estudo foi possível utilizar métodos de etnografia longitudinal com investigação em múltiplos sítios, mas, por outro lado, surgem questões sobre a objetividade do observador, que são resolvidas com o método de "objetivação participante" de Bourdieu.

Durante toda sua carreira Pierre Bourdieu debateu questões de objetividade e subjetividade em pesquisa social. Bourdieu geralmente é citado na Geografia apenas em estudos sobre capital social, mas suas ideias sobre subjetividade em pesquisa influenciaram geógrafos culturais (CRESSWELL, 2013). A preocupação de Bourdieu com a objetividade científica data de sua experiência na Argélia como soldado francês conscrito entre 1955 a 1957 que foi obrigado a fazer pesquisa etnográfica entre os pastores e agricultores berberes durante a guerra de independência. Depois de deixar o serviço militar ele se tornou professor universitário na Universidade de Algiers e participou de um grupo de intelectuais franceses e argelinos crítico à ocupação colonial, até ser forçado a deixar o país. Com base nesta experiência, o etnógrafo voltou para França um sociólogo crítico (GOODMAN, SILVERSTEIN, 2009; NICE, 1978; SCHULTHEIS, 2013).

Bourdieu contrastou duas abordagens em pesquisa social, uma mais subjetiva e outra mais objetiva, que ele tentou mediar através de sua teoria de prática dialética. Na primeira abordagem de etno-fenomenologia, atribuída a Marcel Mauss, o etnógrafo tenta explicitar a experiência primá- 
ria do mundo social da população estudada. A segunda abordagem, de Lévi-Strauss, da hermenêutica sincrônica estruturalista, privilegia o ponta de vista do etnógrafo. Este, porque não faz parte da realidade social local, consegue ser mais objetivo e construir modelos atemporais de relações sociais segmentadas em dimensões econômicas, familiares, lingüísticas, mitológicas, etc. Bourdieu critica ambas abordagens porque aceitam ingenuamente o comportamento idealizado do grupo social estudado que frequentemente não é observado no dia-dia na prática. A estrutura social é estática enquanto a prática é dinâmica, e envolve indivíduos improvisando estratégias flexíveis que ajustam o comportamento idealizado à conveniência do momento (BOURDIEU, 1978, 29, 78). A posição de Bourdieu foi elaborada no meio de um debate famoso entre Sartre [1963(1957)], que pregava a subjetividade existencialista, e, Lévi-Strauss [1969(1962)], que defendia a objetividade científica. Mauss é citado por Bourdieu no lugar de Sartre e mais tarde dos etnógrafos pós-estruturalistas e pós-modernistas.

No fim de sua carreira, Bourdieu se interessou pela sociologia de intelectuais. Em Homo academicus, originalmente publicada em 1988, e em publicações de seus alunos, o grupo de Bourdieu mostrou como tópicos e métodos de pesquisa refletiam as origens sociais de um intelectual, quanto ao seu gênero, idade, afiliação religiosa, nacionalidade e, sobretudo, linhagem de pensamento sediada em instituição acadêmica específica que, por sua vez, é inserida em uma tradição intelectual nacional. Assim sendo, o pensamento de um intelectual é fruto de diferentes "subconsciências transcendentais acadêmicas". Por causa desta influência, existe uma contradição básica na pesquisa social, envolvendo o observador participante imerso no estudo de um universo social que, ao mesmo tempo, é sujeito e objeto, que age e que se observa agindo, que observa o comportamento social de outros enquanto idealmente participa do mesmo. Através da "objetivação participante" o pesquisador reconhece seus preconceitos e tenta controlar os mesmos. Assim sendo, é necessário refletir sobre si, para, em seguida, entender outras realidades sociais (BOURDIEU, 2003, 282-287).

Reconhecer a possibilidade de preconceitos é um bom começo para uma pesquisa, mas a etnografia é mais do que isso. Um segundo passo seria retornar à ideia de Bourdieu da observação de prática através do tempo e não se satisfazer apenas aprendendo regras sociais idealizadas. Como meu orientador de doutorado, Peter Rivière, sempre dizia, "após um mês de trabalho de campo você acha que sabe de tudo, mas depois de seis meses você descobre que não sabe de nada". Com isso, ele queria dizer que no espaço de um mês um pesquisador somente apreende as regras idealizadas e que mais observação revela importantes exceções às regras quando indivíduos flexibilizam seu comportamento visando atender seus interesses e ao mesmo tempo tentam justificar ações que contradizem as regras. Dessa forma, a etnografia bem feita envolve anos de pesquisa e não se limita ao uso de métodos qualitativos e de entrevista semi-estruturada durante algumas semanas ou meses de trabalho de campo (veja CLOKE et al., 2004, p. 169-205 para mais sobre a etnografia em pesquisa geográfica).

Assim sendo, no presente estudo utilizo a "objetivação participante" para superar preconceitos e limitações pessoais que podem interferir negativamente no estudo de pescadores e turistas da costa sul fluminense. Procurei controlar como minha formação social como homem, americano naturalizado brasileiro, membro da classe média alta e residente na Zona Sul do Rio de Janeiro, poderia gerar interpretação tendenciosa. Na pesquisa, ser um turista veterano da área de estudo tinha suas vantagens. Sobretudo, o longo contato com a baia de Sepetiba permitiu observação 
participativa por décadas, pois o olho experiente de um pesquisador experiente nunca está fora do expediente, quando não está fazendo pesquisa "formal". A simples presença em si possibilitou observar eventos na área de estudo que raramente seriam vistos em pesquisa formal com prazo delimitado. Foram notadas através dos anos mudanças lentas em vestimenta, gostos da música, comportamentos sexuais e afiliação religiosa, que foram provocadas pela crescente incorporação metropolitana da área. Por exemplo, certo dia um filho de pescador imitou os turistas fazendo "wake surf" puxado por uma canoa. Isso aconteceu uma única vez e nunca mais, e foi tão rápido que não deu tempo nem para fotografar.

Bourdieu ensinou a importância da trajetória intelectual do pesquisador. A Ecologia Política foi a abordagem teórica escolhida para nortear os dois períodos de pesquisa formal porque fui orientado no Mestrado por um antropólogo formado por Kroeber na Universidade da Califórnia em Berkeley. O primeiro período de pesquisa em 1985-1988 foi influenciado pelo trabalho do sociólogo Michael Redclift nesta linha de pesquisa e assim evitou as limitações da pesquisa geográfica e antropológica na Ecologia Política da época. Quanto ao gênero do observador, a pesca é uma atividade notoriamente masculina no país, mas também pesquisei o trabalho de mulheres e de adolescentes no setor turístico, que hoje seria chamada sua contribuição dentro da divisão sexual do trabalho para modos de vida multifuncionais. Também foram investigados movimentos sociais protestando a poluição urbano-industrial que começou a aparecer na época em função da expansão da região metropolitana na baia de Sepetiba (veja HOEFLE, 1992 para os resultados da pesquisa).

Com tempo as questões socioambientais pesquisadas foram assumindo uma dimensão global na maneira que a baia de Sepetiba foi incorporada no eixo industrial Rio-São Paulo. Empresas nacionais e transnacionais instalaram indústrias e portos de exportação e importação, fazendo com que a pesquisa assumisse um caráter multiescalar, acompanhando mudanças na própria Ecologia Política no período (FORSYTHE, 2004; PEET et al., 2011; HUBER, 2017).

O segundo período de pesquisa formal foi realizado em 2011 e 2012 quando foi utilizado um método longitudinal levantando a história de vida das famílias de pesca estudadas no primeiro período. Aplicando a etnografia de múltiplos sítios de investigação de Marcus (1995), que abraça a globalização, "foram seguidas as pessoas pelo processo", estudando a permanência e a emigração de pescadores e de seus filhos $(n=98)$ à medida que a baia de Sepetiba foi sendo transformada de uma zona rural à periferia da região metropolitana (Figura 1). O modelo de V. Smith (1977) de tipos de turista e esperança de amenidades urbanas foi atualizado e usado para identificar diferentes tipos de ator social que constroem modos de vida multifuncionais na área de estudo (Tabela 1). 


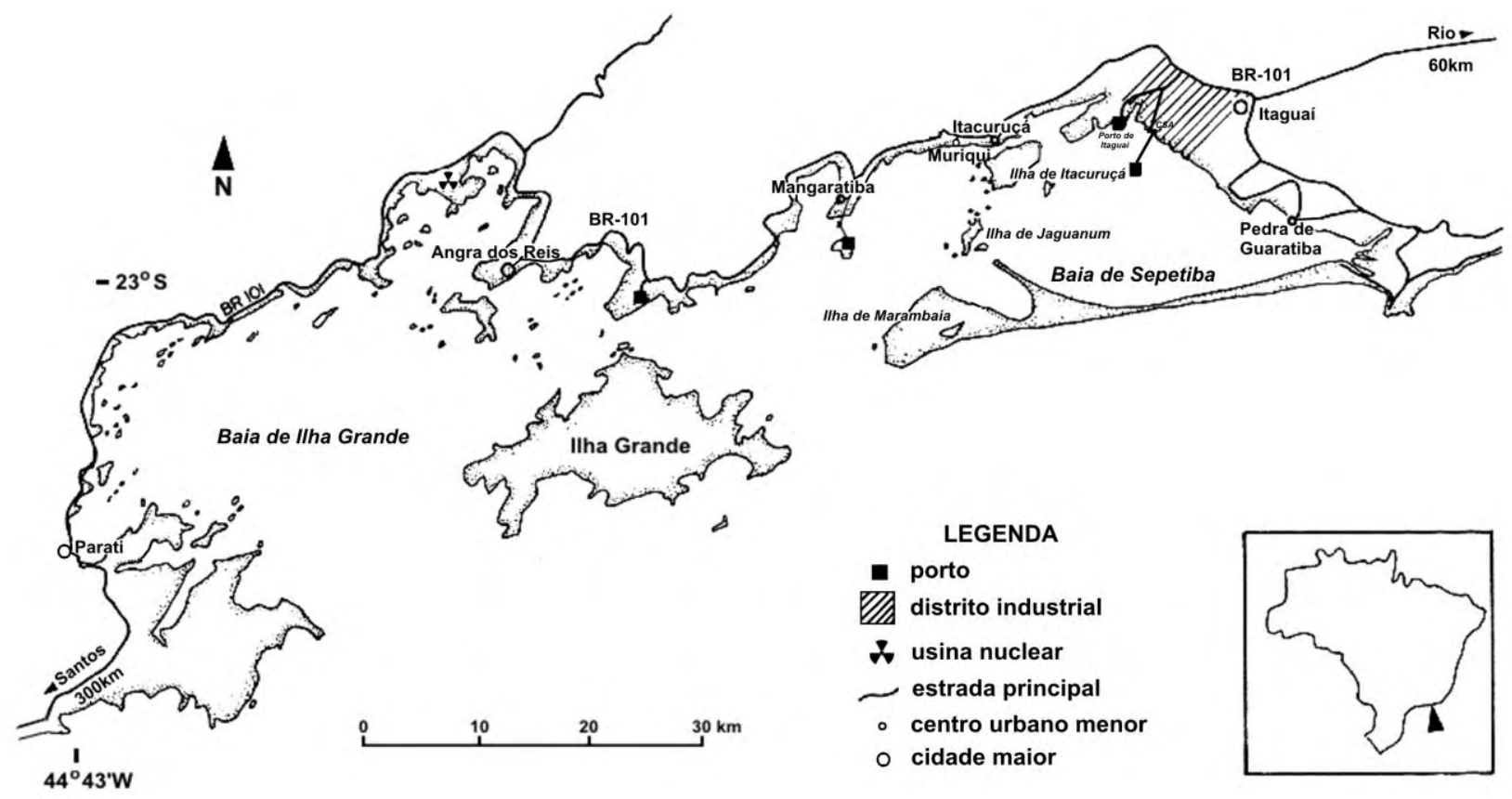

Figura 1. As baías de Ilha Grande e de Sepetiba. Adaptado de: Hoefle (1992).

Tabela 1. Tipo de turista, volume e expectativas.

\begin{tabular}{lll}
\hline \multicolumn{1}{c}{ Tipo de turista } & \multicolumn{1}{c}{ Volume de turistas } & \multicolumn{1}{c}{ Adaptação aos costumes locais } \\
\hline Aventureiro & Muito poucos e raramente vistos & Aceita plenamente condições locais \\
\hline Alternativo e veterano & Poucos, mas vistos & Adapta bem a condições locais \\
\hline Elite & Raramente ou ostensivamente vistos & Cria enclave de amenidades urbanas \\
\hline Massa incipiente & Fluxo regular & Procura provisão de amenidades urbanas \\
\hline Massa & Fluxo contínuo & Espera provisão de amenidades urbanas \\
\hline Pacote & Fluxo em grande escala & Exige provisão de amenidades urbanas \\
\hline
\end{tabular}

Fonte: adaptado de: V. Smith (1977, p. 12).

\section{Caiçaras e turistas aventureiros no paraíso tropical antes de $1970 ?$}

A pesca artesanal e o turismo de praia no país normalmente induzem imagens de paraísos tropicais que são violados e corrompidos pelo turismo em massa. Um estudo conhecido deste tipo, intitulado apropriadamente Assault on Paradise, mostra como comunidades de pescadores deram lugar a condomínios fechados de veranistas na região metropolitana de Salvador (KOTTAK, 1986, 2009). Assim sendo, é necessário deixar claro desde o início que há muito as baias de Ilha Grande e de Sepetiba deixaram de ser qualquer tipo de paraíso. No início do século XIX o 
comandante do quartel militar em Mangaratiba era dono de um engenho de açúcar, localizado na praia da Estopa na Ilha de Jaguanum, no qual utilizava trabalho forçado de presos de sua cadeia (FRIDMAN, 2001). Na segunda metade do mesmo século as encostas das ilhas foram desmatadas para plantar café e testamentos citam escravos como propriedade herdada. Na mesma época a área de estudo era entreposto importante no contrabando de escravos durante o bloqueio britânico. Na mesma praia da Estopa famílias eram separadas antes de serem levadas ao mercado de escravo do Rio de Janeiro. Na época do primeiro período de pesquisa as pessoas idosas consideravam a praia mal assombrada, onde em noites de tempestades sudoestes podia ser ouvido o barulho de correntes e criança chorando.

Após um período de abandono no início do século XX o cultivo de bananas foi introduzido e, ainda hoje, existe algumas roças de banana espalhadas pelas ilhas. Nos anos de 1960 um dinamarquês com experiência anterior com plantations coloniais na Indonésia chegou e novamente foram desmatadas as encostas das ilhas para fazer carvão. Alguns anos mais tarde o mesmo homem comprou uma terça parte da ilha de Jaguanum e tentou violentamente expulsar os pescadores e os poucos veranistas na área comprada. Podemos concluir que longe de ser um paraíso tropical como anunciado em propaganda de excursões de saveiro, talvez "inferno tropical" seria uma caracterização mais fiel ao passado da área de estudo (Figura 2).

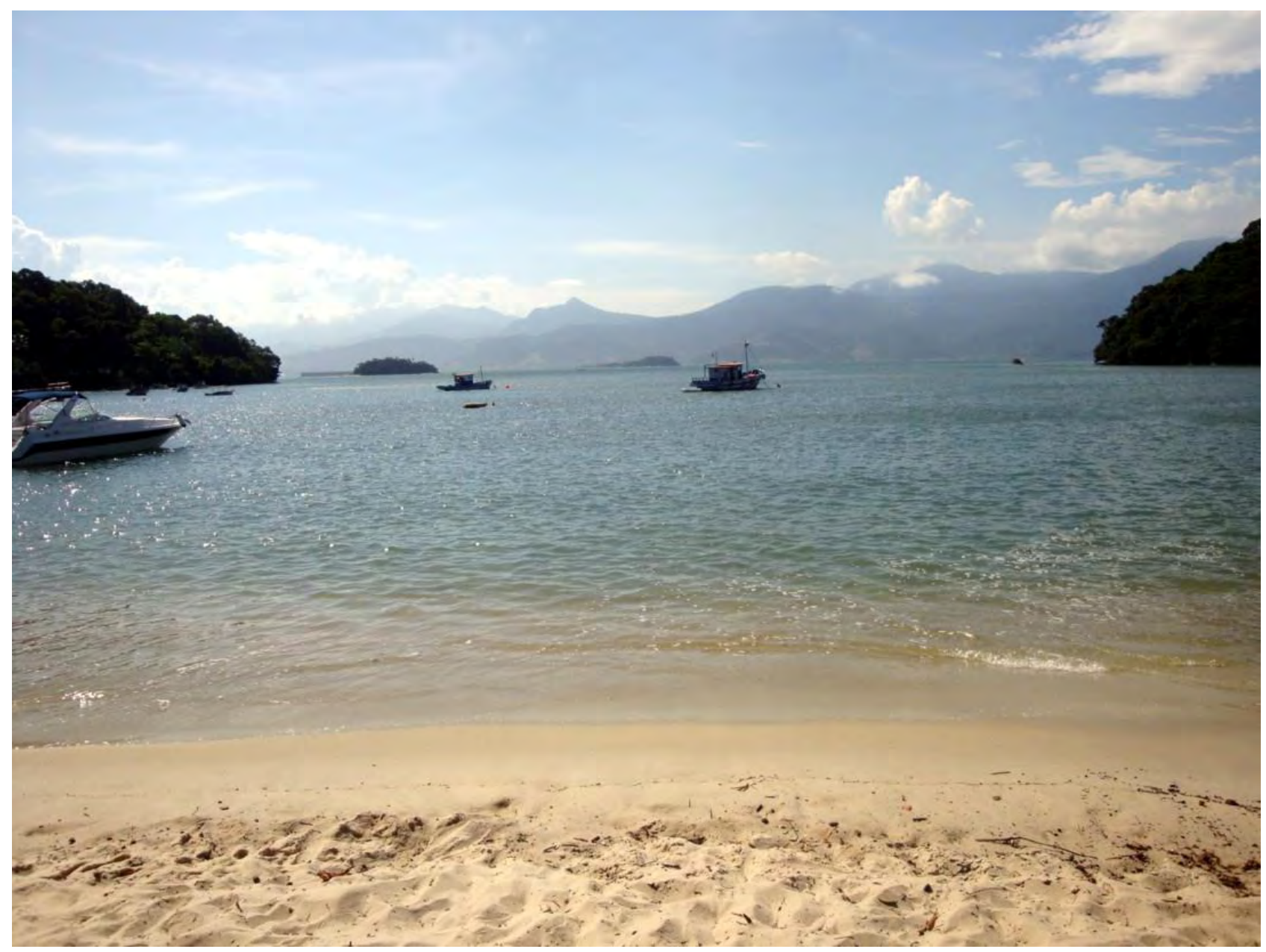

Figura 2. A beleza atual da praia da Estopa oculta um passado sinistro. Fonte: Pesquisa de campo (2011). 
Apesar do seu passado e a proximidade à cidade do Rio de Janeiro até 1970 era difícil o acesso terrestre às baias de Ilha Grande e Sepetiba e o turismo praiano no estado se desenvolveu a leste da capital na região dos Lagos. Nesta área, veranistas substituíram pescadores e saleiros nas restingas e nas lagunas. A retirada de mangue e a poluição sanitária eliminaram a pesca nas lagunas de forma que só restou a pesca de alto mar. Contudo, nesta atividade é difícil um pescador artesanal se tornar proprietário de embarcação grande suficiente para navegar longe da costa (BIASOTTO, 1995; GUIMARÃES, 1987; LIMA, 1993; PEREIRA, 1949).

$\mathrm{Na}$ costa do sul fluminense as montanhas chegam à beira do mar e os picos alcançam mais de 1.000 metros de altitude. O clima é entre os mais chuvosos do país que dificultava a construção de estradas e ainda hoje complica a manutenção. Após 1914 havia uma ferrovia pequena que atendia Itacuruçá e Mangaratiba. A área ficou fora do eixo de desenvolvimento industrial do vale da Paraíba do Sul e consequentemente o povoamento ficou esparso. Pescadores locais eram pouco articulados a mercados e uma economia artesanal existia até a construção da BR-101 (Rio-Santos). Métodos de pesca eram intensivos em mão-de-obra e a maioria dos instrumentos de produção e bens de consumo era feita pelos próprios pescadores ou obtida de artesões locais.

Assim sendo, antes de 1970 caiçaras praticavam uma forma de pesca e de agricultura que pode ser considerada pré- ou não-produtivista multifuncional (cf. WILSON, BARTON, 2015). A pesca de semi-subsistência gerava alguma renda monetária que era usada para comprar algumas necessidades básicas e a agricultura era puramente para o auto abastecimento. Canoas eram movidas a vela e a remo e em consequência os pescadores só iam ao porto uma ou duas vezes por mês. Redes de espera colocadas próximas à superfície eram empregadas na pesca artesanal. A abertura nas redes era de 30 a $50 \mathrm{~mm}$ que não apanhavam peixes pequenos e camarão de forma que a pesca artesanal era sustentável.

Na divisão doméstica do trabalho as mulheres não pescavam, mas podiam ajudar no conserto das redes (mais sobre isso abaixo). Geralmente, dois homens trabalhavam juntos numa canoa e a divisão da pescada era em quatro partes: uma para o dono da canoa, uma para o dono da rede e uma para cada homem. Mão-de-obra familial era utilizada, geralmente um pai e um filho ou genro ou dois irmãos. O pai ou um irmão era dono da embarcação e o filho ou outro irmão da rede, de forma que a divisão era feita por partes iguais. Redes de algodão ou sisal eram utilizadas e fabricadas pelos próprios pescadores como também as canoas utilizadas e as casas de moradia.

Assim sendo, os pescadores tinham acesso aos instrumentos de produção e à moradia. Como observou Diegues (1983), os caiçaras da costa brasileira eram camponeses. Na literatura clássica sobre camponeses (MENDRAS, 1978; WOLF, 1976, 1982) este tipo de personagem rural utiliza poucos insumos que necessitam capital para sua aquisição. Os três "Ms" que definem a produção capitalista - a mão-de-obra assalariada, a matéria prima e insumos comprados e o uso da maquinaria - eram praticamente ausentes entre os caiçaras.

Em 1938 uma carta náutica elaborada pela Marinha mostra quinze casas de pescador na ilha de Jaguanum, a maioria situada em frente do saco de Marambaia que ainda hoje é um importante lugar de pesca (Figura 3). Em função da distância da ilha de Jaguanum ao continente, por volta de sete quilômetros, o turismo era quase inexistente. Na década de 1940 um alemão construiu uma casa rústica numa extremidade da praia da Estopa, no local onde existiu o engenho de 
açúcar no passado. O homem foi preso durante a Segunda Guerra Mundial e nunca foi visto novamente. O caseiro dele tomou posse da casa e eventualmente a vendeu para um veranista anos depois. Veremos abaixo que esta prática se repete no tempo, mostrando que a "grilagem" funciona nos dois sentidos.

Nos anos de 1950 um inglês construiu uma casa rústica no outro extremo da praia da Estopa. Ele era gerente de uma fazenda de gado da Frigorífica Anglo localizada no continente em Coroa Grande. O veranista cruzava a baia numa canoa de pescador. Na época houve visita de membros da Família Real da Inglaterra que ficaram alguns dias na casa dele. Dormiram em redes na varanda e acharam a estadia uma aventura fantástica. No início dos anos de 1960 mais dois ingleses que trabalhavam no país também construíram casas simples na praia. Na mesma época o dinamarquês citado acima levantou uma casa mais pomposa no meio da praia. Os veranistas estrangeiros tentaram apropriar linguisticamente a praia mudando o nome para a "praia dos ingleses", mas o nome não emplacou entre os pescadores.

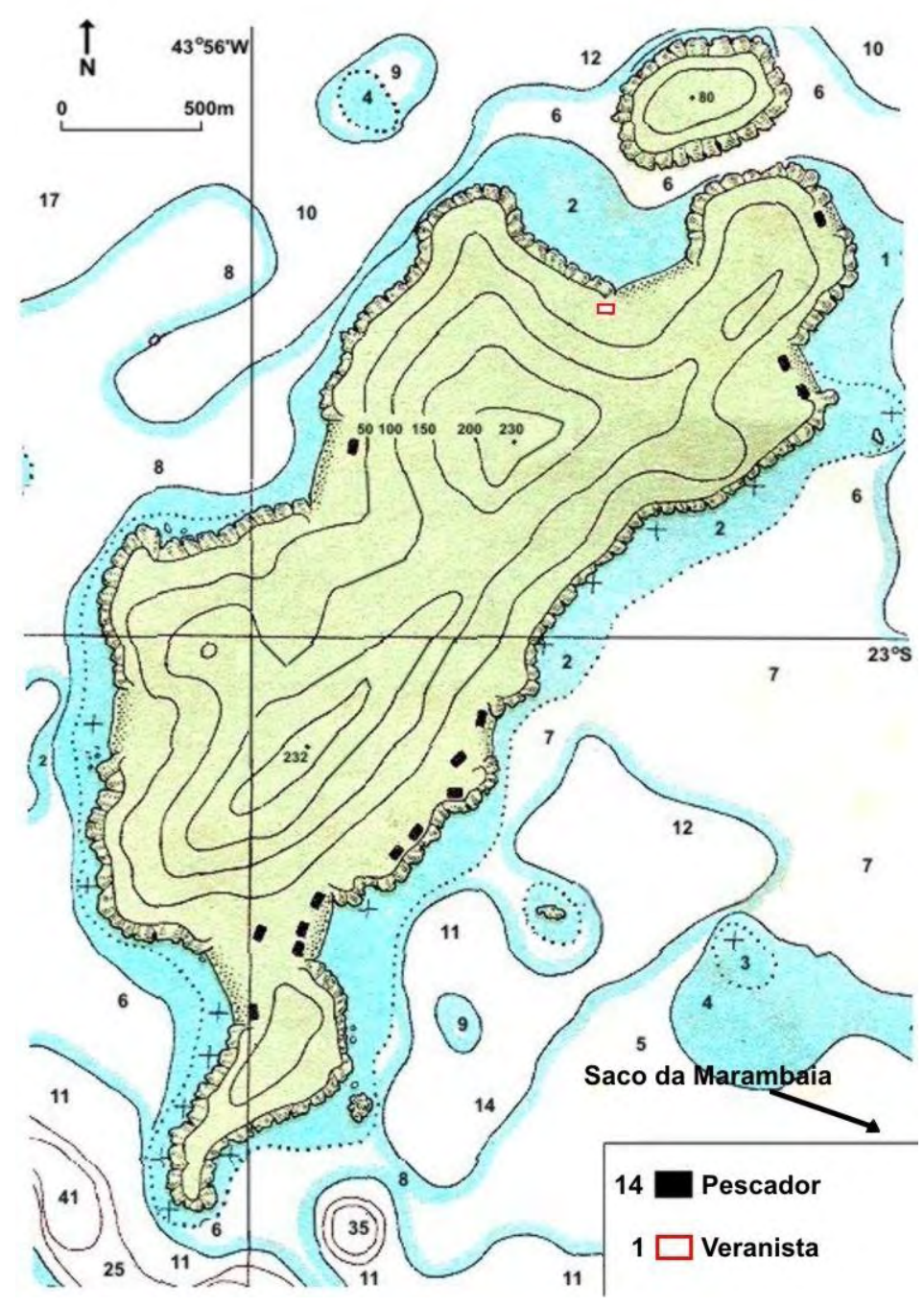

Figura 3. Casas de pescadores e veranistas na ilha de Jaguanum, em 1938. Adaptada de: Marinha do Brasil (1938). 
Em 1969, para desgosto dos estrangeiros um brasileiro adquiriu uma casa simples na praia da Estopa. Ele era um advogado capaz e defendeu os pescadores e veranistas do grileiro dinamarquês. O advogado ficou indignado com o comportamento colonial deste, baseado no uso da violência e da propina a funcionários municipais. Ele realizou um minucioso levantamento jurídico da história fundiária da ilha de Jaguanum, buscando documentos sobre herança até as Sesmarias. Chegou a consultar a Torre do Tombo em Lisboa e mandou um especialista traduzir o português arcaico para a língua corrente. Como era esperado, descobriu que os documentos do grileiro eram falsos e no tribunal chegou-se a um acordo no qual os pescadores e veranistas podiam ficar. O dinamarquês frustrado acabou morrendo de alcoolismo e hoje suas terras estão em dívida ativa com o governo federal e municipal por falta de pagamento de impostos. Em 2004 quando o advogado faleceu na ilha, em respeito os pescadores solenemente carregaram seu caixão para ser embarcado na praia.

Obviamente, estes veranistas não são turistas típicos do tipo que faz o passeio na baia numa excursão de saveiro e volta para Rio de Janeiro no mesmo dia. Usando a tipologia de Smith (1977), os veranistas podem ser caracterizados como "turistas aventureiros e veteranos". Este tipo de turista passa dias e semanas na sua casa de veraneio e é atraído pela simplicidade da vida no lugar. Não provoca grandes mudanças locais, mas também não cria muitos empregos. Podia pagar até um salário mínimo a um pescador para tomar conta da casa ou pagar algumas diárias à mulher do pescador para fazer limpeza na casa quando ele estava presente.

\section{Pesca capitalizada de camarão e turismo de elite entre 1970 e 1990}

A construção da estrada Rio-Santos nos anos de 1970 permitiu a penetração do capital urbanoindustrial oriundos do Rio de Janeiro e de São Paulo nas baias de Ilha Grande e Sepetiba. A costa leste e norte fluminense ficou cada vez mais urbanizada e a costa sul tornou-se uma hinterlândia rural com atividades de lazer de fim de semana. Como é comum em regiões metropolitanas, por um lado, surgem ameaças a pequenos produtores rurais, mas por outro lado, os mesmos são beneficiados pelo acesso a um mercado consumidor maior (BRYANT, JOHNSTON, 1992; ROBINSON, 1990). A possibilidade de vender mais produção a preços maiores permitiu pescadores artesanais entrarem num processo de capitalização durante o auge da pesca de pequena escala entre 1970 e 1990. Pescadores passaram a usar redes de nylon, que são mais resistentes e duráveis necessitando menos consertos. Nas canoas substituíram a vela e o remo por motores a diesel e alguns pescadores compraram pequenos barcos de pesca.

Ao mesmo tempo, artesanato local foi substituído por produtos fornecidos por especialistas do continente ou mesmo por fábricas localizada fora da área de estudo. Além disso, deixaram de praticar a agricultura e começaram a comprar mais comida de fora. Com canoas motorizadas e maior ênfase na produção comercial os pescadores passaram a ir ao continente uma vez por semana para vender o pescado e comprar comida. Em outras palavras deixaram de ser caiçaras. Com as mudanças cresceu a necessidade de dinheiro porque agora como pescador capitalizado tinha que comprar quase todos os instrumentos de produção e bens de consumo. A eliminação de trabalho artesanal e a competição com firmas de traineiras levaram os pequenos pescadores a concentrar quase que exclusivamente no camarão. Com isso eles ganharam mais renda, mas sua 
dependência no mercado e sua especialização em camarão aumentaram os riscos imediatos da pesca e ameaçaram seu modo de vida ao longo prazo quando estoques de camarão diminuíram nos anos de 1990.

Os pescadores de pequena escala adotaram várias estratégias para se adequar aos novos riscos de produção e para se capitalizarem lentamente. Inovações técnicas eram introduzidas em etapas, ao mesmo no tempo que continuaram usando mão-de-obra familiar, que é remunerada por produção de acordo com o resultado da pesca e não por salário fixo. A divisão do pescado foi adaptada ao processo de capitalização. Uma quinta parte foi introduzida na divisão para o dono do motor, que geralmente era o dono da canoa, tornando a divisão desigual. No processo de tornar-se um pescador capitalizado, primeiro, um jovem ganhava uma rede do pai ou comprava uma rede com sua parte do pescado numa canoa de um parente. Em seguida, ele comprava ou herdava uma canoa, geralmente com 6 metros de comprimento e equipada com um motor diesel de 9 hp, que custava por volta de US\$2.500 em 1985. Após isso, ele podia comprar outra canoa, ou junto com seus irmãos adquirir uma pequena embarcação de pesca de camarão, geralmente com 7 a 8 metros de comprimento e com motor de $22 \mathrm{hp}$, que na época custava por volta de US $\$ 10.000$. A renda média anual de tripulantes entrevistados em 1985 era US\$1.824 enquanto donos de canoa ganhavam US\$5.629 e donos de embarcações de camarão realizavam uma renda anual de US\$10.470. Assim sendo, para um tripulante comprar uma canoa eram necessários 1,4 anos de renda e para uma embarcação 5,5 anos de renda que era possível fazer quando feita por etapas, isto é, através de capitalização flexível.

Ascensão social era bem menor no setor empresarial de pesca que progressivamente penetrou as baias de Ilha Grande e de Sepetiba durante os anos de 1980. Uma embarcação maior exigia mais capital inicial. Este setor ainda existe hoje, mas também foi afetado negativamente pelo declínio em recursos pesqueiros após 1990, que em parte era resultante das próprias práticas produtivistas insustentáveis do setor. Neste setor, são usadas grandes redes de arrastão e embarcações equipadas com sonar para localizar e posicionar a rede em frente de um cardume. As redes têm aberturas mais finas de $10 \mathrm{~mm}$ e são arrastadas ao longo do fundo, revolvendo tudo e apanhando qualquer peixe ou crustáceo no caminho. Geralmente há interesse numa única espécie - camarão, sardinha ou corvina - e o resto é devolvido morto ao mar. Obviamente, este tipo de pesca representa séria ameaça aos recursos marinhos e pescadores locais reclamam que várias espécies foram drasticamente reduzidas.

O investimento necessário para comprar uma embarcação maior para a pesca de camarão, ou de traineira, para sardinha, é elevado para os padrões locais. Uma embarcação de camarão, com 10 a 12 metros de comprimento e um motor diesel de $60 \mathrm{hp}$, custava por volta de US\$25.000 em 1985 e uma traineira, com dezoito metros e um motor de $110 \mathrm{hp}$, por volta de US\$45.000. Na época os tripulantes entrevistados ganhavam em média US\$6.246 enquanto o dono de uma embarcação de camarão apurava US\$25.496 e o dono de traineira de sardinha US\$104.400. Um tripulante, portanto, tinha que investir entre 5,7 a 7,2 anos de renda respectivamente para comprar uma embarcação do setor empresarial. Assim sendo, um tripulante na época era apenas um trabalhador com participação no produto, sem perspectiva de tornar-se um pescador independente.

Com o boom de turismo nos anos de 1980 esta atividade passou a predominar nas ilhas próximas ao continente que eram de acesso mais fácil para investidores urbanos. Em levantamento de moradias na ilha de Itacuruçá realizado em 1987 foram encontradas apenas 50 casas de 
pescadores num total de 238. As outras edificações eram casa de veranistas, alojamento de caseiros, hotéis e restaurantes. As poucas concentrações de pescador se davam em áreas de mangue infestadas de mosquitos, que não atraía veranista.

O oposto acontecia na ilha de Jaguanum que é distante do continente. Os pescadores prosperavam do lado dos veranistas. Para ter acesso à ilha um veranista tinha que ser dono de uma lancha e um turista que queria visitar a ilha por um dia tinha que entrar num passeio de saveiro. Essas opções de transporte eram caras na época, o que limitou o número de casas de veranistas, hotéis e restaurantes. Consequentemente, com a exceção da praia em que havia um hotel falido, havia pescador morando em todas as praias da ilha e algumas praias não tinham veranistas. As casas de veranistas, restaurantes e o hotel falido ocupavam apenas $43 \%$ das edificações da ilha (Figura 4).

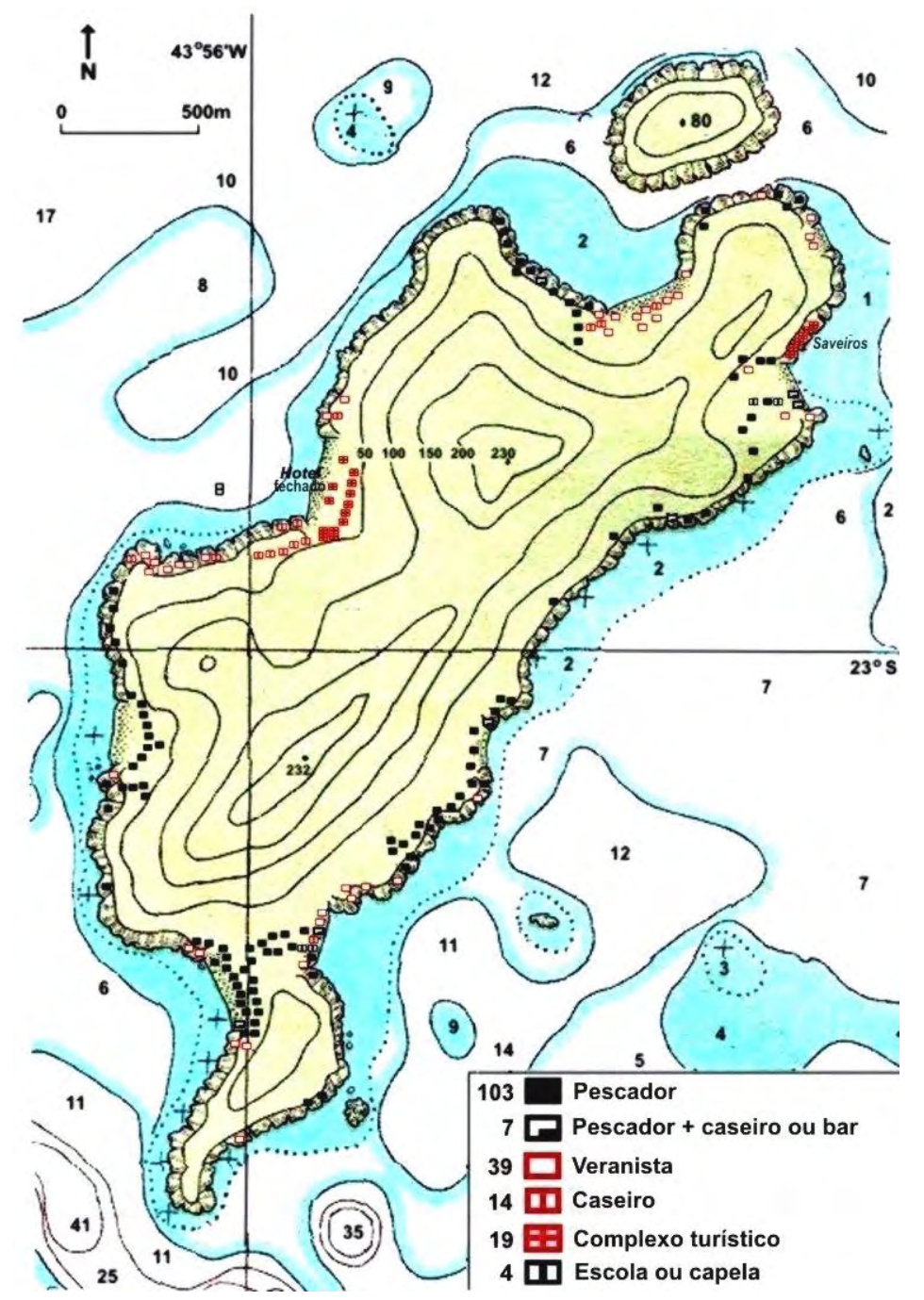

Figura 4. Casas de pescadores e turistas na ilha de Jaguanum em 1987. Adaptada de: Hoefle (2014). 
Emprego no setor turístico beneficia principalmente as mulheres e adolescentes masculinos locais, e a fonte de renda era importante durante a baixa temporada de pesca em abril e maio. Membros de famílias de pescadores trabalhavam em tempo parcial como empregada doméstica e caseiro nas casas de veraneio, e durante o pique da estação turística no verão como cozinheiro e garçom nos restaurantes e bares. O problema maior com este trabalho era a baixa remuneração, que pagava o salário mínimo, apenas US\$720 ao ano em 1985. Além disso, o tipo de trabalho realizado - jardinagem e outras tarefas domésticas - não era considerado atividade masculina. Esta atitude somente mudou nos anos de 1990 quando a pesca entrou em declínio.

Durante o auge dos passeios de saveiro envolvendo turistas estrangeiros nos anos de 1980 havia mais de 50 saveiros baseados em Itacuruçá. A propaganda vendia a imagem de um paraíso tropical, com fotografias coloridas de papagaios, caipirinha e mulheres em biquínis minúsculos, alegando que os saveiros visitavam ilhas pristinas (Figura 5). Certa vez, o autor viu uma propaganda deste tipo numa agência de turismo em Londres. A excursão incluía translado de ida e volta do Rio de Janeiro para Itacuruçá em ônibus com ar condicionado, raridade no país na época, e o passeio de saveiro na baia de Sepetiba, ao som de sambistas vestidos em camisa florida tipo turista. Esta forma de turismo criou emprego, que era considerado trabalho masculino, mas que só pagava o salário mínimo. Em comparação, se ganhava bem melhor na pesca de pequena escala. Entre as famílias de pescadores entrevistadas na ilha de Jaguanum, 93\% dos filhos de idade adulta permaneceram na ilha e trabalhavam na pesca.

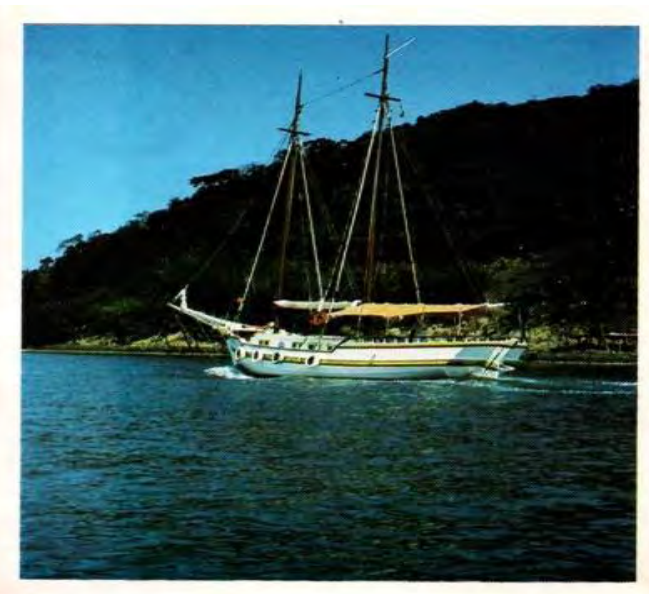

TOUR 11 - PARADISE ISLAND Departures: Daily

Forget your jacket, sweaters, neckties and city clothes, take your shoes off, and let us give you a chance to reach that elusive and delicious feeling that indeed you have gotten away from it

A schooner cruise across the shimmering emerald green waters of Sepetiba Bay, brings you to tropical island: cool clear water invites swimming and wading. A the tropical lunch is served during the cruise.

This is PARADISE ISLAND - just there, 90 minutes away from Rio aboard our airconditioned motorcoaches.

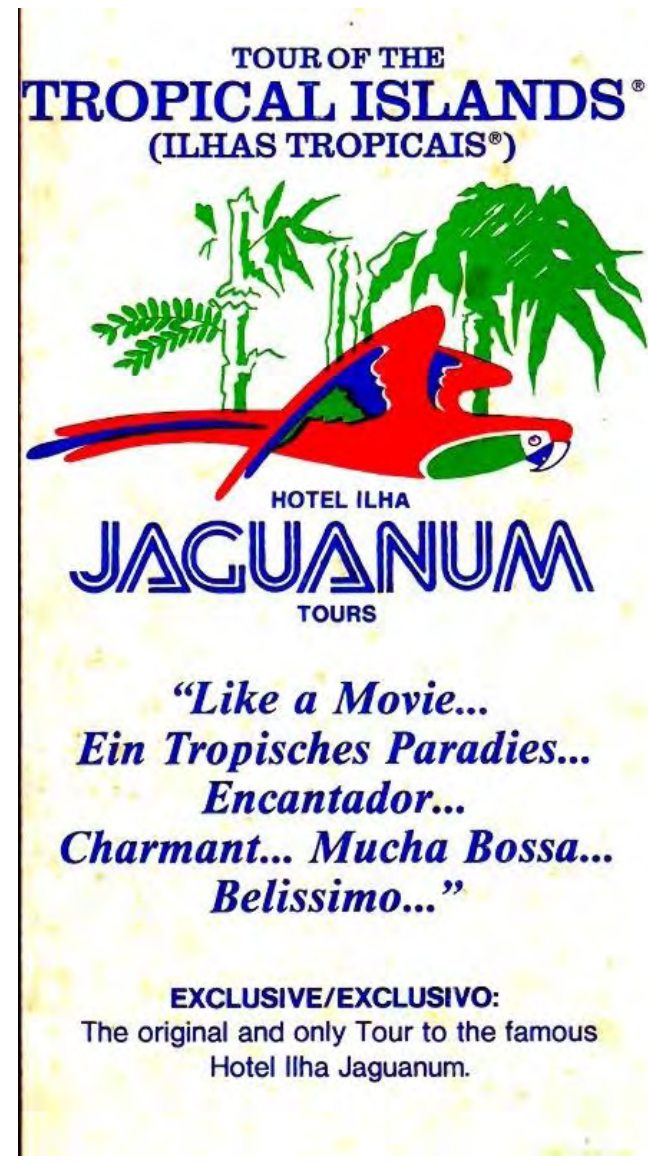

Figura 5. Propagandas de excursão de saveiro nos anos de 1980. 
Durante este período o veraneio expandiu no continente e nas ilhas próximas envolvendo indivíduos de classe média com residência principal na zona central e oeste da região metropolitana. Os veranistas das ilhas distantes eram membros das classes alta e média alta oriundas de bairros nobres do Rio de Janeiro e de São Paulo, sendo o que Smith (1977) chamou de "turista elite". Este tipo de turista é mais exigente na sua estadia fora da cidade e instala melhorias na sua casa de campo. Nesta situação um turista veterano pode se sentir obrigado a reformar sua casa para acompanhar os vizinhos. Na ilha de Jaguanum este processo envolveu trocar casas simples de tijolo com piso de cimento para casa maior com piso de cerâmica decorada ou de pedra, instalar louças e acabamentos mais sofisticados nos banheiros, colocar luz a gerador, etc. O turista de elite também construía quebra-mar, colocava cerca separando a praia de sua propriedade e placas em múltiplas línguas instruindo os turistas de saveiro a não entrar no terreno (Figura 6). A paisagem era domesticada. Grama bem cortada substituía areia no terreno. Os arbustos de baixo das árvores eram cortados em áreas com mata, causando erosão. Troncos de coqueiro eram pintados com cal. Até árvores perto da praia eram podadas para não servir de sombra para turista de saveiro e de lancha.
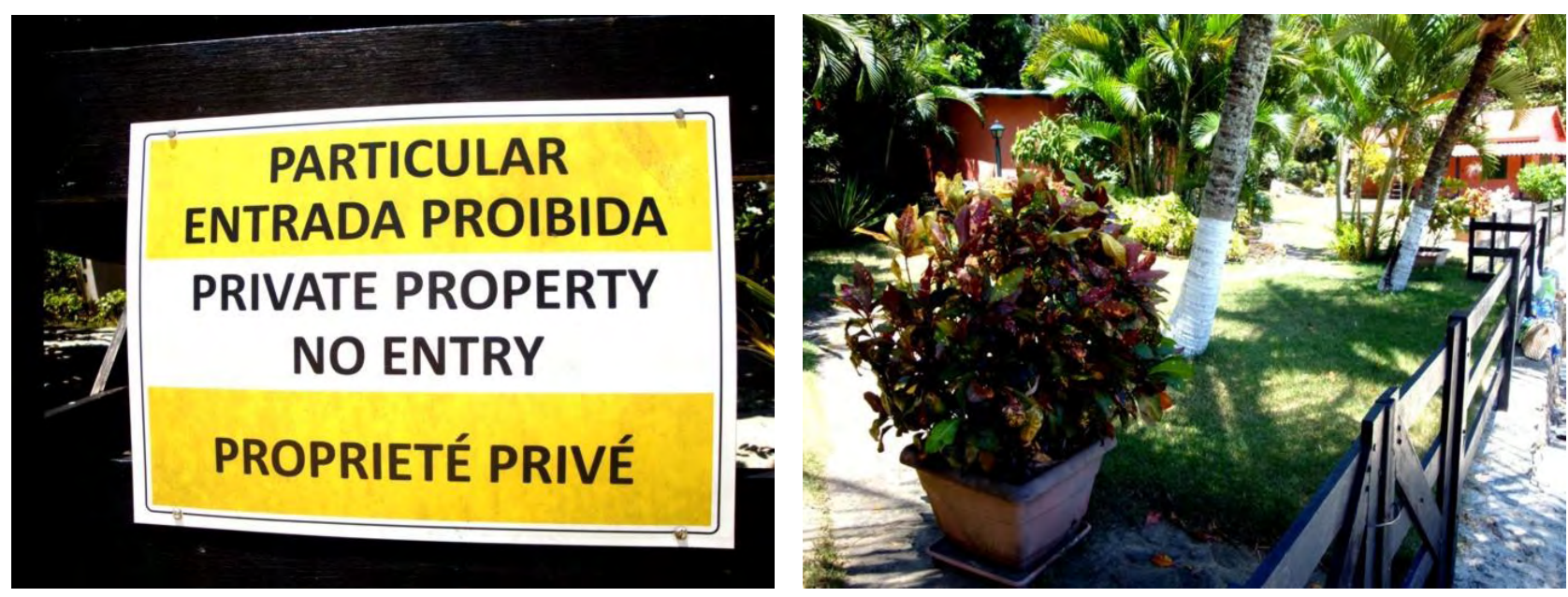

Figura 6. Propriedade de turista elite. Fonte: Pesquisa de campo (2011).

Relações entre pescador e veranista ficaram mais frias, mas mesmo havendo menos contato entre eles o modo de vida dos pescadores foi influenciado pela presença dos turistas. Com maior renda monetária ganha na pesca comercial a população local substitui suas pequenas casas de taipa e telhado de palha para casas maiores de alvenaria e telhado de placas de amianto. Agora era possível comprar eletrodomésticos, especialmente televisão à bateria e rádio-gravador. Alguns pescadores cavaram poços para ter água encanada em casa. Os jovens passaram a imitar as novidades de vestimenta e escutar música popular nas cidades que causou conflito entre gerações sobre questões de gosto e modéstia. Em outras palavras os jovens deixaram de ser "rural" para ser "suburbano". Protestantismo foi introduzido e teve boa aceitação entre famílias com problemas de alcoolismo, um problema crônico entre os pescadores. Contudo, esta tendência foi freada quando o pastor, que vinha pregar regularmente na ilha, certa vez engravidou uma adoles- 
cente.

A pesca comercial e o veraneio provocaram uma mudança ambiental benéfica: a regeneração de floresta nas encostas (Figura 7). Os pescadores pararam de plantar lavoura e os veranistas raramente situavam casas fora da área plana da praia. Um veranista estrangeiro reflorestou suas encostas com o objetivo de aumentar a quantidade de água disponível. À medida que a floresta retornou às encostas, a fauna ficou mais abundante. Passou a ser comum avistar gambá, esquilo e mico e as vezes macaco grande. Contudo, a infestação de mosquito ficou pior.
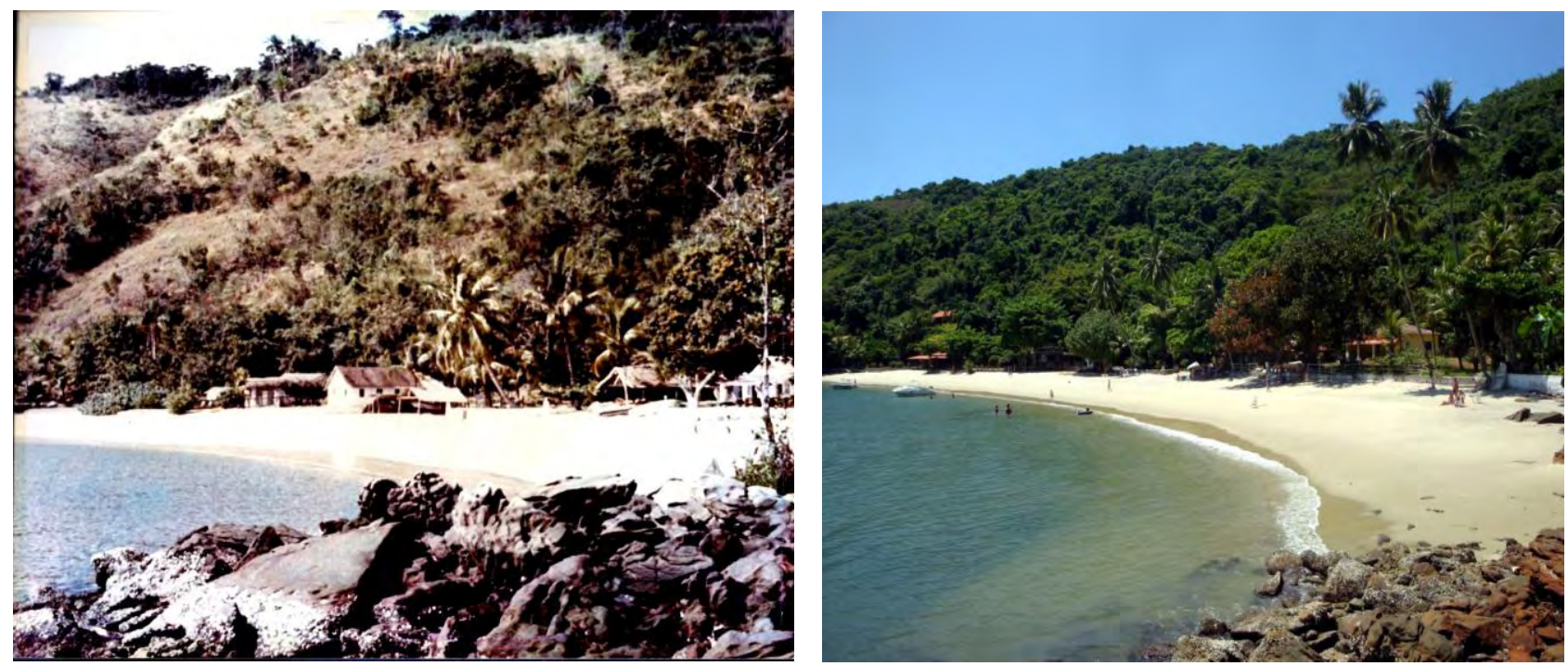

Figura 7. Regeneração de floresta nas encostas na ilha de Jaguanum. Fontes: B. Bicalho (1969), pesquisa de campo (2011).

Com o aumento do número de veranistas e hotéis na baia de Sepetiba o conflito sobre o uso da pouca água disponível ficou cada vez pior. Foi construído um hotel na ilha do Jardim, outro na Praia Grande na ilha de Itacuruçá e um resort no lado oposto da mesma ilha. A localização destes hotéis próxima ao continente facilitou acesso de hóspedes e maior ocupação de quartos. Um hotel situado na ilha de Jaguanum, contudo, fechou logo após ser aberto porque não conseguiu atrair hóspedes a um lugar tão distante. Os veranistas novos e os hóspedes de hotel eram indivíduos urbanos que demandavam água encanada e chuveiro quente e seu consumo maior criou tensões com os pescadores, particularmente na estação menos chuvosa quando água era mais escassa. A prática de gastar água para molhar grama e lavar o cais irritava os pescadores que tinham que buscar água para beber em fontes, sendo que o ponto de captura de água para os veranistas era anterior ao da fonte. Pessoas urbanas e estrangeiras desconheciam a legislação sobre sequestro de água em ilhas, e consideravam a água sua propriedade particular. Este problema ficou pior na praia da Estopa quando o dinamarquês dinamitou uma cachoeira que existia na sua propriedade visando utilizar a pedra para construir um quebra-mar. O rio secou e só restou uma pequena fonte no lado oposto da praia que era inadequada para abastecer uma população crescente de veranistas. 
Enquanto a pesca de pequena escala prosperou nos anos de 1980 uma tempestade se formou no horizonte. As traineiras comerciais com rede de arrastão e equipamento de sonar reduziram o número de peixes. Entre 1980 e 2010 a população da região metropolitana aumento em 35\% e atingiu 11.838.752 habitantes (IBGE, 2010). A área edificada se expandiu a oeste, abrangeu a parte oriental e central da baia de Sepetiba e o município de Itaguaí foi incorporado na região metropolitana (Figura 8). No continente, a terra agrícola foi convertida em conjuntos habitacionais e condomínios, o mangue foi aterrado e aumentou o fluxo de esgoto sem tratamento que corria nos rios e canais para a baía.

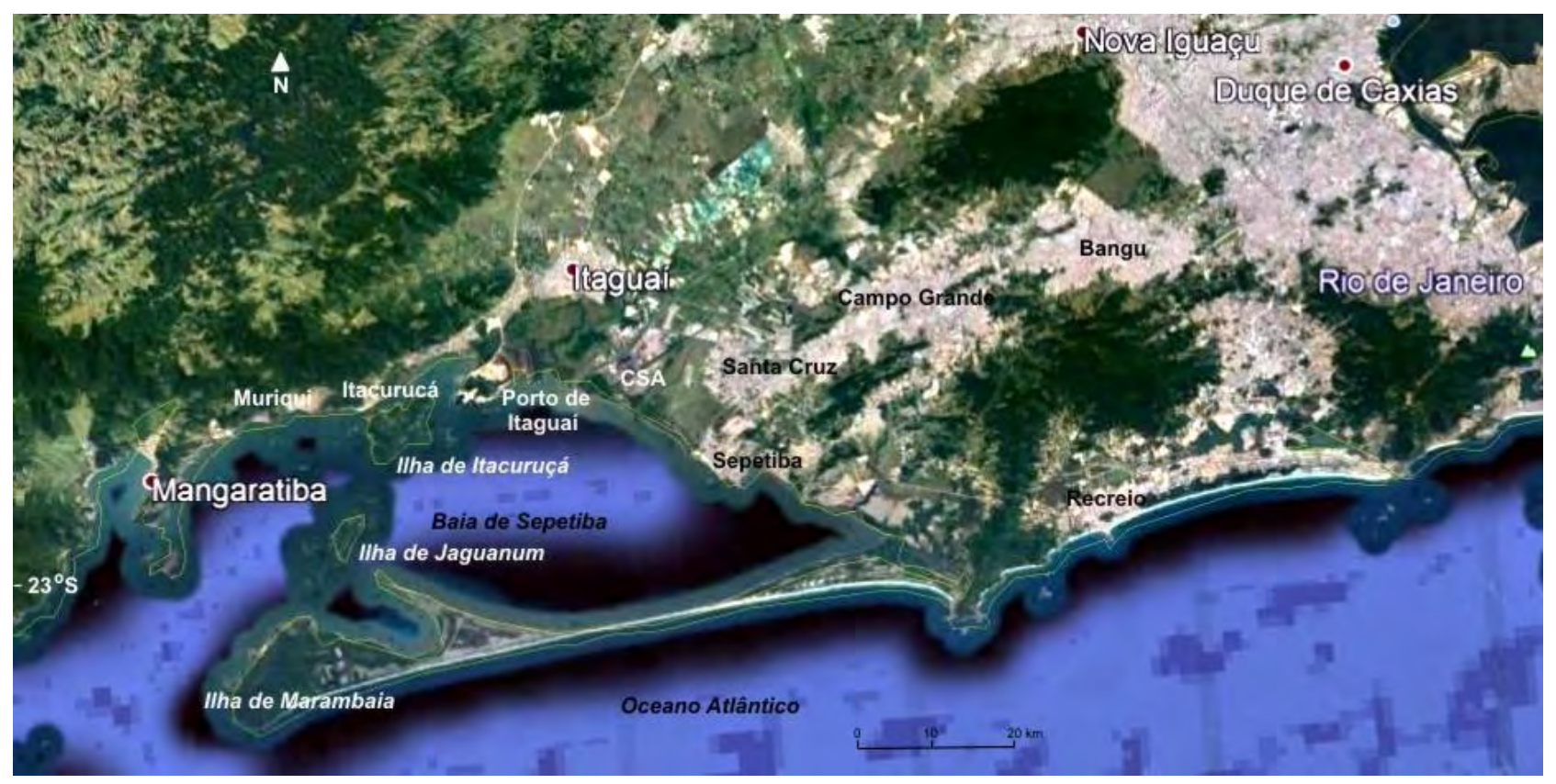

Figura 8. A baía de Sepetiba hoje. Fonte: Google Earth Pro (2018).

O impacto da globalização no país levou à instalação de nova indústria e infraestrutura logística na região. Novos portos foram construídos na baia de Sepetiba para exportar minério e aço, que expandiu exponencialmente acompanhando a demanda global, particularmente da Ásia. Os portos mais problemáticos do ponta de vista ambiental foram aqueles localizados no lado oriental da baia num imenso manguezal que era área criatória de peixe e crustáceo. O porto da Ilha da Madeira foi construído próximo a um distrito industrial já existente e necessitou dragagem em grande escala para abrir canal de navio numa parte rasa da baia. Através dos anos o porto quadriplicou sua capacidade para exportar minério e tornou-se o principal porto de contêiner da região metropolitana (Figura 9). A indústria também expandiu, destacando a siderúrgica CSA ThyssenKrupp. A siderúrgica foi projetada para atender $30 \%$ da demanda mundial para chapa especializa- 


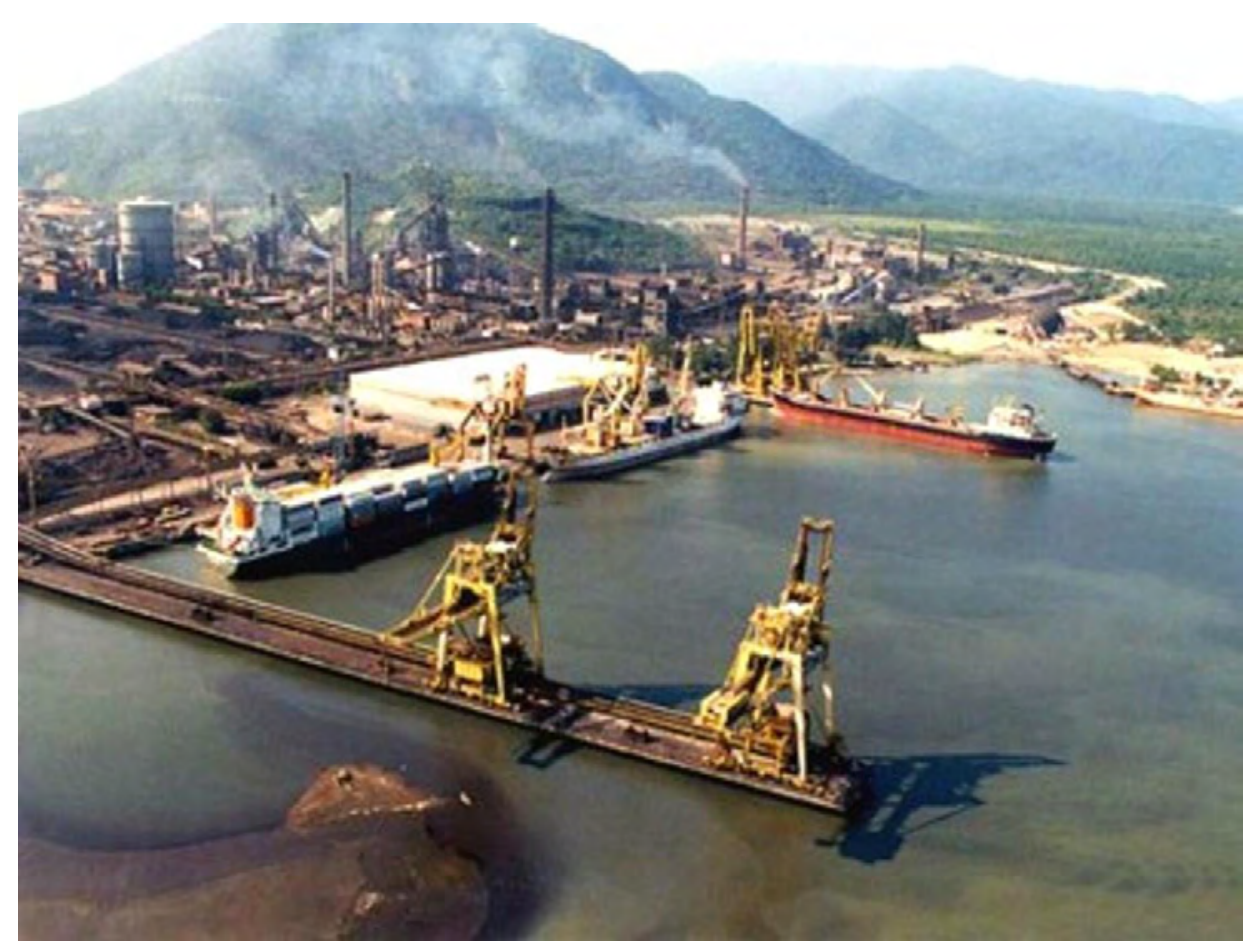

Figura 9. Porto de minério e contêiner e complexo industrial da baia de Sepetiba.

Fonte: Fiocruz (2010).

Os recursos pesqueiros caíram drasticamente na parte oriental da baia em decorrência de vazamentos de poluentes. Houve dois grandes desastres ecológicos, um em 1996 e outro em 2002, quando a chuva forte rompeu os diques de contenção de uma fábrica falida de cromo e a baia foi contaminada por metais pesados (Figura 10). O colapso da pesca nos dois anos e o declínio progressivo dos estoques de peixe após de 1990 causaram um surto de emigração das ilhas. Das famílias de pescadores entrevistadas nos anos de 1980, 75,5\% dos indivíduos saíram, quase todos para bairros de baixa renda nos núcleos urbanos do continente (Figuras 11 e 12). As opções de trabalho nesta área são: tripulante de saveiro, garçom de restaurante e ajudante de pedreiro na construção civil. Tripulantes de saveiro ganham o salário mínimo que era US $\$ 4,450$ por ano em 2011, mas hoje há poucas vagas disponíveis. O turismo internacional e de elite deslocou-se para Angra dos Reis e Parati e hoje são apenas dez saveiros operando regularmente em Itacuruçá. A maior renda é encontrada na construção civil: US\$6,000 por ano como ajudante de pedreiro e US\$9.000 como pedreiro. Metade das mulheres que foram para o continente é empregada doméstica que ganha o salário mínimo e as outras são do lar. Os adolescentes são estudantes e não trabalham. No lado positivo, deve ser destacado que os ex-ilhéus também foram atraídos aos núcleos urbanos do continente buscando aprimorar sua educação e para ter acesso aos serviços de saúde. 


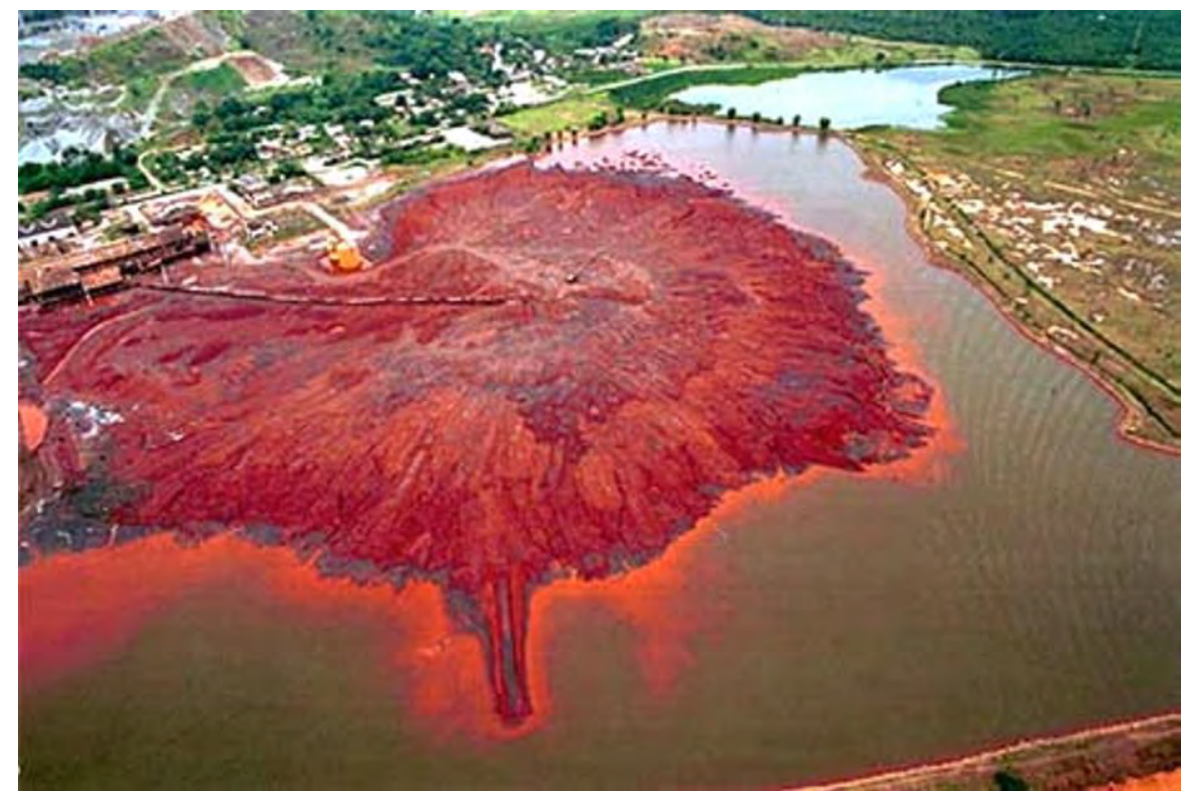

Figura 10. Chuva forte estoura diques de retenção levando metais pesados para a baia de Sepetiba. Fonte: Baradó (2011, p. 4).

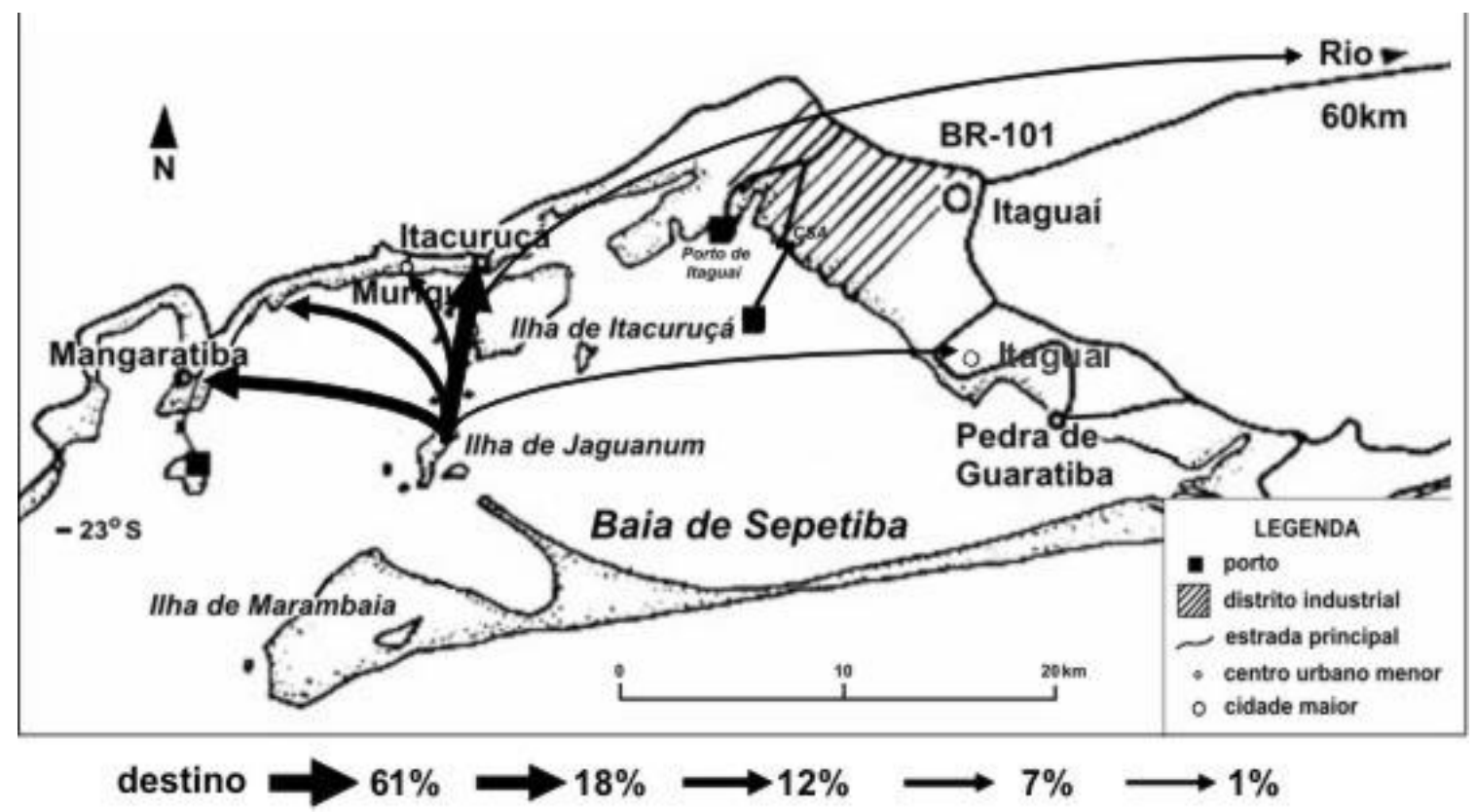

Figura 11. Migração de pescador para o continente. Fonte: pesquisa de campo (2011). 


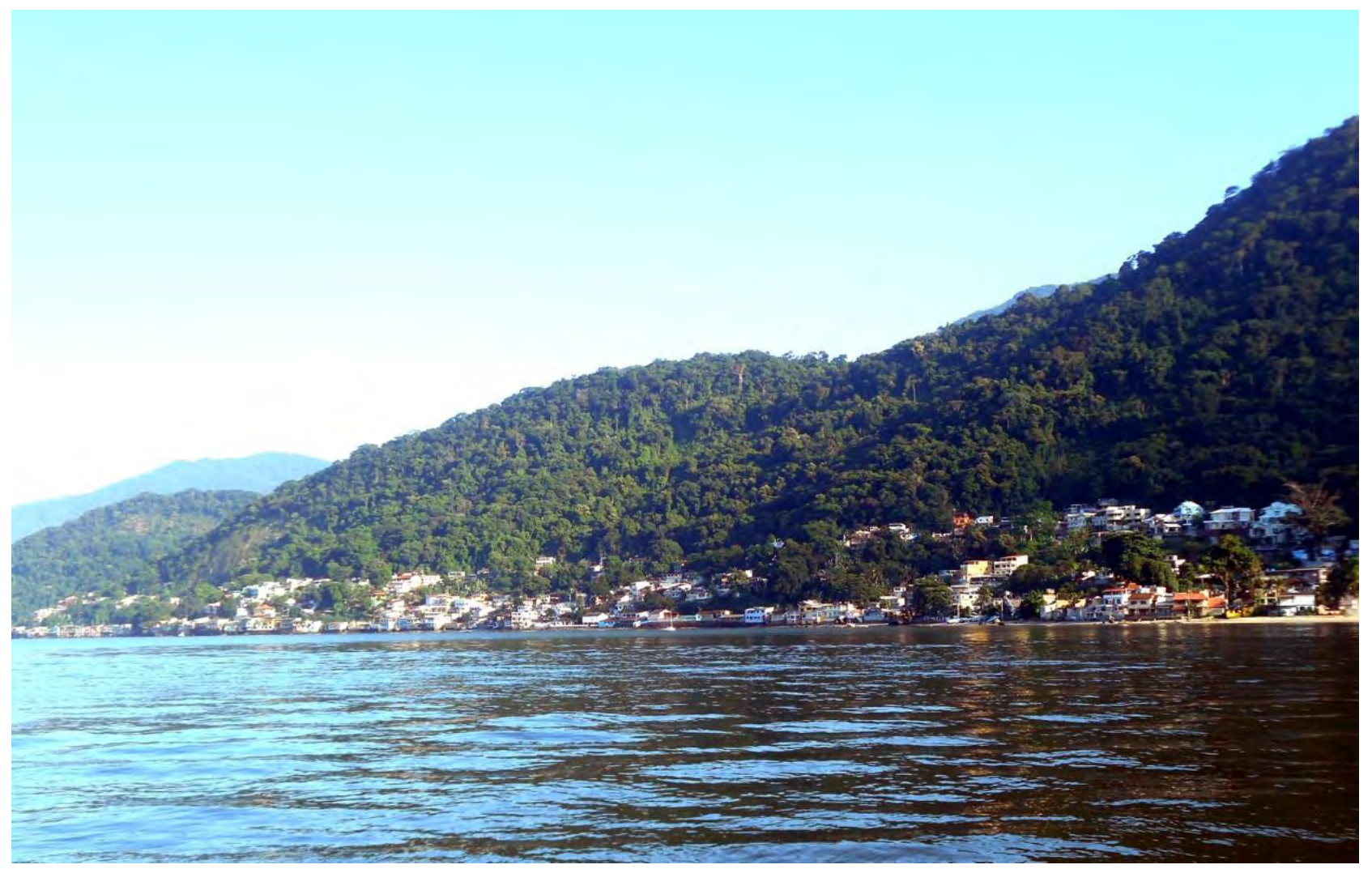

Figura 12. Bairros populares localizados em encostas sujeitas a deslizamentos em Itacuruçá. Fonte: pesquisa de campo (2018).

Nas ilhas o turismo em massa substituiu o turismo de elite do período anterior. Antes da crise econômica de 2015, classes médias e médias altas emergiram nos subúrbios do oeste da região metropolitana. Indivíduos com maior renda, como por exemplo médicos e comerciantes, compraram lanchas caras custando mais de $R \$ 120.000$ e nos fins de semana passam o dia nas praias das ilhas distantes da baia de Sepetiba. A praia da Estopa virou "point". Turistas com menor poder aquisitivo, por sua vez, vão de "taxi boat", levados por pescadores que buscam aumentar sua baixa renda atual. Enquanto os turistas de saveiro podiam passar meia hora na praia, estes turistas passam o dia inteiro. Bebem grandes quantidades de cerveja, fazem churrasco e tocam em volume alto música funk e de outros gêneros. O vento do mar leva o cheio de gordura queimada para dentro das casas de veraneio. Com grande número de lanchas ancoradas na praia, cada uma tocando uma música diferente, é inevitável a poluição sonora. Os veranistas mais velhos foram atraídos às ilhas na procura de paz e silêncio e os donos de lancha querem fazer festa. Um grupo quer descansar da cidade e o outro grupo quer reproduzir a cidade no seu lazer. Um visitante inglês ficou admirado com o barulho produzido e afirmou que no seu país era caso de polícia.

Contudo, o bote de fiscalização da Capitania dos portos raramente aparece. Quando de fato passa, o bote provoca um corre-corre de donos de lancha que retiram suas embarcações ancoradas próximas à praia, prática que é proibida. Quando o bote vai embora todos logo recolocam suas lanchas de volta na beira da praia. Obviamente esta prática é perigosa devido a grande quantidade de bebida alcoólica consumida. Um caso absurdo envolveu um dono de lancha que 
estava tão embriagado que se recusou a retirar sua embarcação de perto da praia, alegando que estava bêbado demais para pilotar barco. Em 2003 houve um acidente grave provocado por piloto de lancha embriagado que atropelou uma mulher, decepando suas pernas, na praia de Pitangueira, outro "point" na ilha de Jaguanum.

Conflito de percepções do lugar continua noite adentro nos fins de semana. Jovens pescadores são entediados pelo silêncio das ilhas durante a semana e gostam de realizar pequenas festas de funk durante a noite no fim de semana. Veranistas novos também gostam de tocar música alta durante o dia e a noite, podendo começar bem cedo de manhã. Certa vez um veranista mais velho ficou irritado e comentou que "Ninguém merece ser acordado às sete horas da manhã por Tim Maia cantando "Eu sei que vou te amar". Os novos veranistas também usam mais iluminação a noite e deixam luzes de segurança acesas como fariam nas suas casas de subúrbio. Isso foi possibilitado com a chegada da Luz para Todos em 2010. Este tipo de fornecimento de energia é para eletricidade rural. Não é permitida a instalação de iluminação pública, no intuito de não interferir com a fauna silvestre. Alheio a isso, os novos veranistas instalam um número de luzes em frente de suas casas para iluminar a praia e o cais.

Com todas as mudanças ocorridas, muitos dos antigos veranistas venderam ou abandonaram suas propriedades e outros simplesmente morreram. Os poucos que restam evitam fim de semana prolongado e mesmo fim de semana normal durante o verão quando há uma invasão de turistas. Como aconteceu no passado com a casa abandonada do veranista alemão, pessoas locais apropriaram as casas abandonadas e venderam para veranista. Além disso, terreno localizado do lado de casa de pescador pode ser vendido mesmo sendo parte do espolio do dinamarquês (Figura 13). Normalmente um veranista compra casa vazia de pescador que emigrou para o continente. Neste caso, o veranista tira proveito do estado deprimido da pesca e não induz diretamente a emigração. Também existe o contrário, de ex-pescador que mora no continente, mas mantém sua casa na ilha para passar o fim de semana, praticando, assim, uma espécie de veraneio.

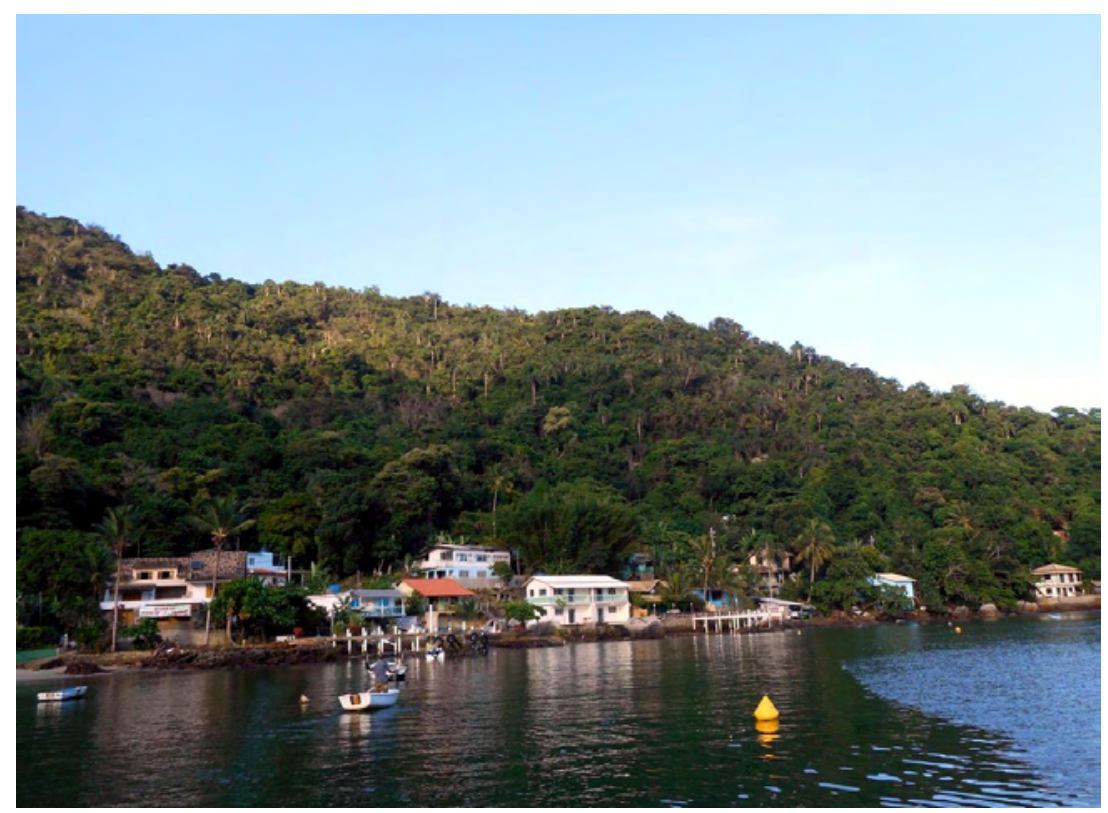

Figura 13. Novas casas de veraneio construídas no meio de casas de pescador na praia da Estopa. Fonte: pesquisa de campo (2018). 
$\mathrm{Na}$ ilha de Jaguanum o número de casas de veraneio aumentou três vezes entre 1988 e 2011, de 39 casas para 124 casas (Figura 14). Esta tendência acelerou quando a eletricidade chegou. Contudo, a Luz para Todos não é projetada para este tipo de consumo. Quando os veranistas chegam e ligam seus aparelhos de ar condicionado o fornecimento cai e todos ficam no escuro.

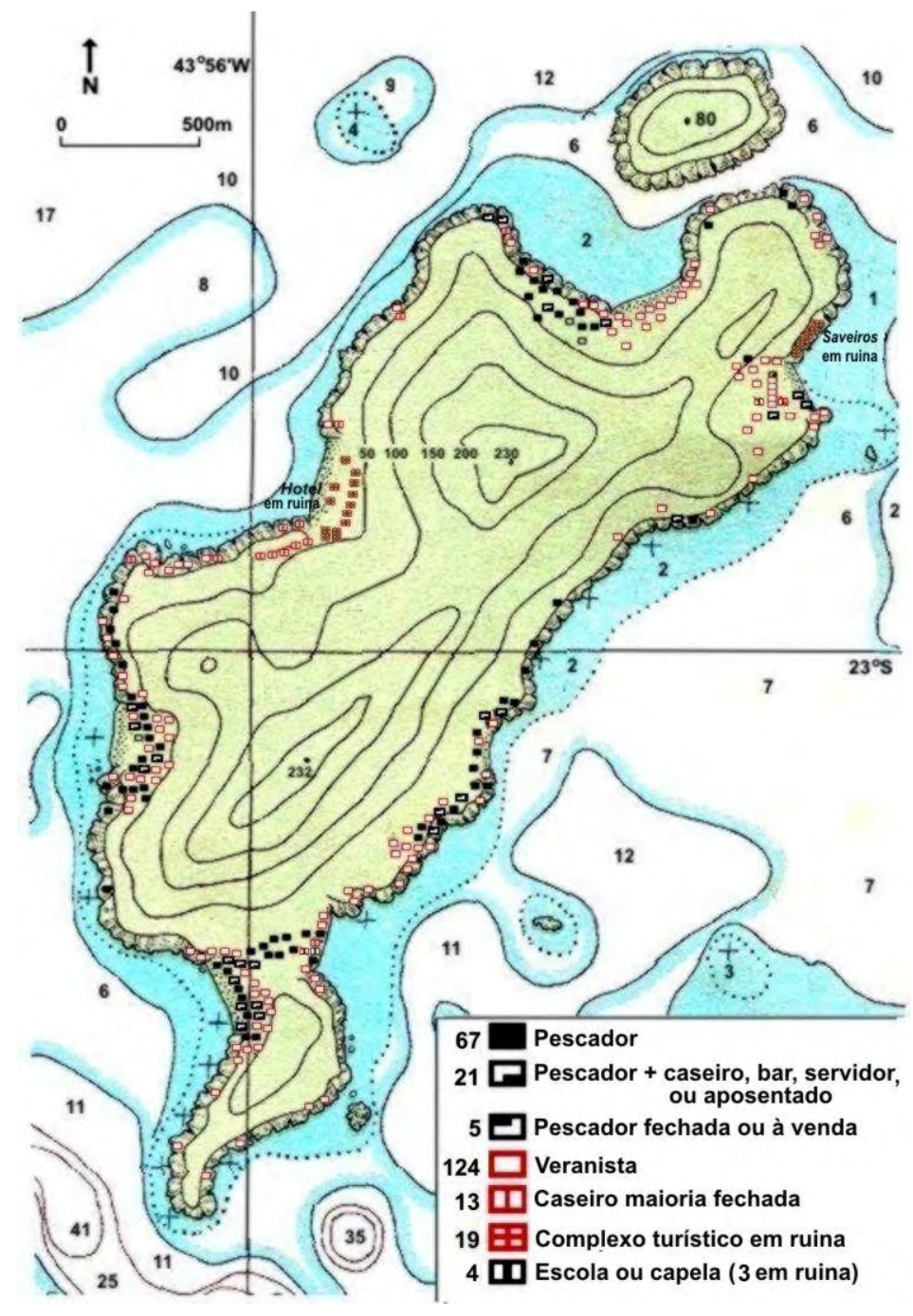

Figura 14. Casas de pescador e veranista na ilha de Jaguanum em 2011. Adaptada de: Hoefle (2014).

Neste quadro, o número de casas de pescador em tempo integral na ilha de Jaguanum caiu de 103 em 1987 a 53 em 2011. Estes pescadores ainda conseguem resultados satisfatórios explorando as águas menos poluídas da parte ocidental da baia. Em 2011 os pescadores entrevistados ganharam de US\$2,970 a US\$9,001 por ano, que é o equivalente de 0,7 a 2 salários mínimos, mas longe da renda obtida nos anos de 1980 que variava de 2,5 a 14,5 salários mínimos. Muitos pescadores outrora prósperos sofreram um processo de descapitalização e substituíram embarcações por canoas e alguns dos mais pobres só usam remo (Figura 15).

Uma mudança cultural foi a entrada de mulheres na pesca. No passado, o costume ditava que mulher não pescava e a presença de uma mulher em uma embarcação dava azar na pesca- 
ria. Antes de 1990 só foi observada uma mulher pescando com o marido durante o período quando seus filhos não eram velhos suficientes para ajudar o pai na pesca. A mulher foi criada no continente numa família agrícola e, antes de casar com pescador de ilha, ela já era acostumada a ajudar na roça. Seguindo seu exemplo, nos anos de 1990, um número de moças começou a pescar com os pais, mas somente antes de casar. Hoje, porém, não há mais mulher pescando. Talvez esta prática fosse uma adaptação a famílias menores e à falta de rapazes da idade certa para ajudar na pesca. Na época dos caiçaras, famílias eram enormes, com casos de mais de dez fiIhos, mas a partir de 1970, o tamanho da família caiu para de dois a cinco filhos. Assim sendo, a estrutura etária da família campesina com grande número de filhos em idade decrescente foi substituída por famílias menores. Hoje no país só se encontram famílias grandes entre camponeses de fronteira na Amazônia (HOEFLE, 2013).

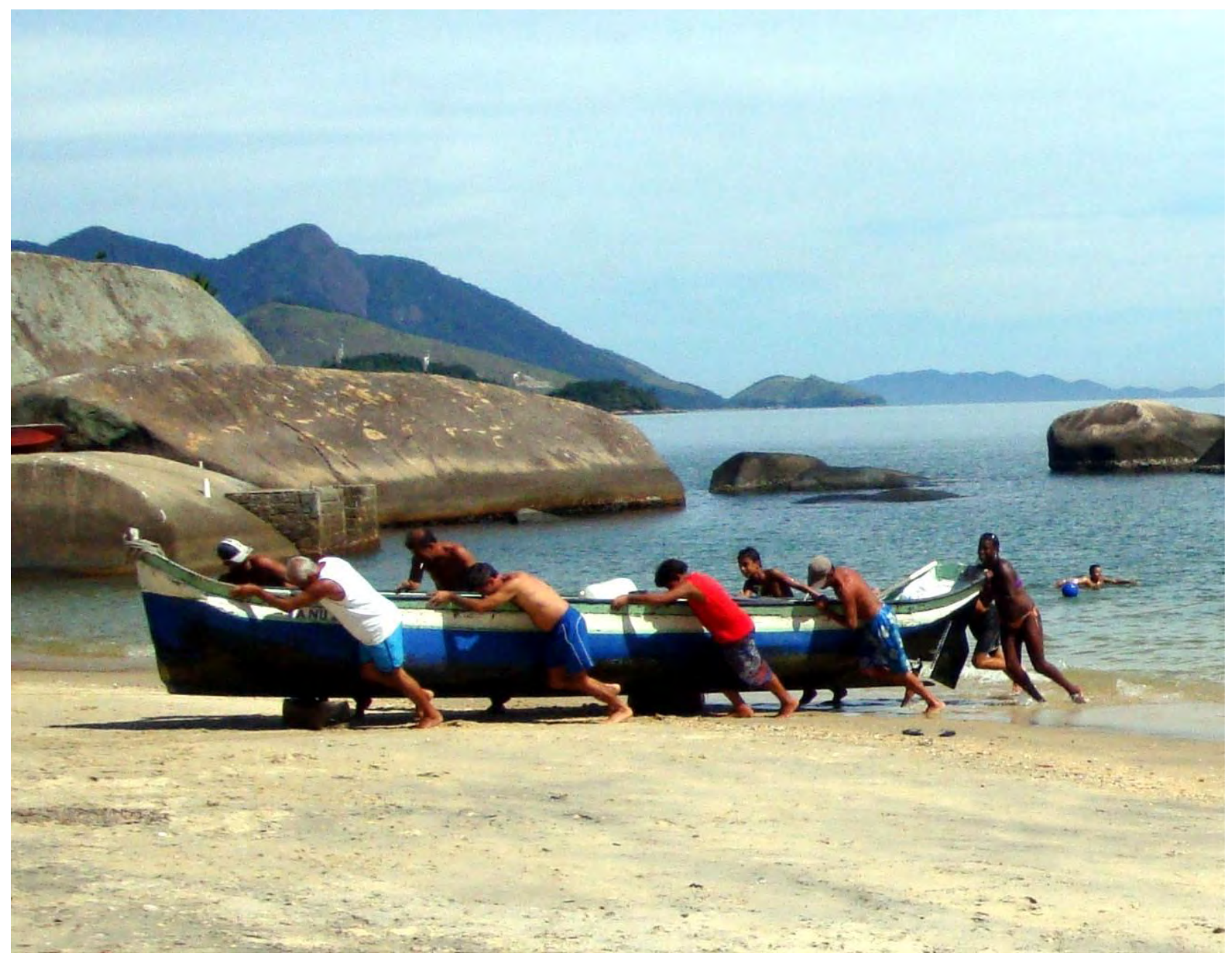

Figura 15. Descapitalização causada por redução da escala de pesca. Fonte: pesquisa de campo (2011).

O número de casas de pescador com múltiplas fontes de renda aumentou de 7 em 1988 a 21 em 2011. São combinados pesca com caseiro, pesca com bar e pesca com serviço público, propiciando, respectivamente, uma renda anual de US\$13.831, US\$13.400 e US\$10.738. Este 
novo fenômeno de multifuncionalidade rural gera maior renda do que aquela ganha por expescadores morando na cidade, mas é limitado o número de empregos nas ilhas que permitem combinar diferentes fontes de renda. O turismo em massa não cria muito trabalho porque os donos de lancha e quem vem de táxi boat só ficam o dia e o movimento deles se concentra no verão. Há um excesso de taxi boats competindo por passageiro de forma que cada um ganha pouco. Os novos veranistas têm casas simples muitas vezes sem terreno e não contratam caseiro em tempo integral. Os turistas trazem comida e bebida de fora e não compram quase nada localmente, mostrando porque Kadt (1979) desaconselhou fundamentar estratégias de desenvolvimento em turismo de massa.

O aumento de poluição marinha e aérea na baia de Sepetiba induziu o surgimento de uma organização não governamental, a SOS Sepetiba, que desde os anos de 1990 tenta construir uma aliança entre os pescadores e os veranistas afetados. Em função de divisões internas entre a pesca de pequena escala e a pesca empresarial foi difícil organizar esta categoria. Entre os turistas, os veranistas de elite foram embora, só ficando veranista de classe média que dispõe de pouca força política. A vida luxuosa dos "famosos" em Angra dos Reis e Parati é destaque nas colunas sociais e em revistas de turismo enquanto reportagens denunciando o desastre ecológico na baia de Sepetiba só aparecem esporadicamente na parte de jornais que trata problemas socioambientais da população de baixa renda, como por exemplo, falta de saneamento básico e deslizamentos provocados por chuva.

A SOS Sepetiba foi espelhada na experiência bem sucedida da SOS Mata Atlântica que atua em conservação nas montanhas. Contudo, a SOS Mata Atlântica abrange os grupos sociais mais poderosos do país, cientistas famosos, profissionais e artistas renomados e tem grandes empresas nacionais e internacionais como parceiros. Além disso, as montanhas da Mata Atlântica são marginais para o agronegócio, o que facilitou a aceitação de promover a conservação nestas áreas (veja HOEFLE, 2019). A situação da SOS Sepetiba é a oposta porque tem que lidar com poderosas empresas nacionais e conglomerados globais, como a CSA, que continuam poluindo a baia de Sepetiba e redondezas no continente, alheias às denúncias e às multas por infração ambiental.

\section{Qual assalto do paraíso?}

Retornando a nossa questão inicial: como caracterizar a relação entre pesca, turismo e desenvolvimento urbano industrial na costa fluminense? Na baia de Sepetiba hoje não existe conflito direto entre turismo e pesca de pequena escala. Fontes de renda oriundas de múltiplas funções são importantes para os pescadores que ficaram nas ilhas, mas a renda total é uma sombra daquela que ganhavam no passado na pesca capitalizada de camarão. Turismo em massa gera pouco emprego local de forma que a melhor caracterização da relação seria justaposição (coexistência). O setor empresarial de traineiras e o desenvolvimento urbano-industrial, por sua vez, entram em conflito direito com pesca e turismo. O primeiro setor usa a pesca predatória e o segundo causa a retirada de manguezal e gera níveis alarmantes de poluição marinha. Em reação, os pescadores locais procuram se engajar em outras atividades, como, por exemplo, fazer transporte de turistas na parte ocidental da baia. Contudo, eles são bem conscientes que ainda podem perder este trabalho 
se a degradação ambiental tomar conta do resto da baia. Todos ficaram aliviados quando foi negada a licença ambiental para um megaprojeto que ligaria a ilha da Madeira por um túnel escavado através da ilha de Itacuruçá com um novo porto a ser construído na ilha da Sororoca. A instalação de um porto no meio da baia seria a sentença de morte da pesca e do turismo que ainda restam.

Também são fracas outras dimensões multifuncionais. Hoje, a baia de Sepetiba não é mais o paraíso ecológico exaltado pelo setor turístico nos anos de 1980. É verdade que houve regeneração de florestas nas encostas, mas o turismo em massa provoca edificação em excesso, gera problemas sanitários, demanda quantidades de água acima da limitada oferta comum em contexto de ilha e aumenta o consumo de eletricidade a níveis que ultrapassam a capacidade da infraestrutura. Em termos culturais, o turismo de saveiro ao som de samba que servia turista estrangeiro foi substituído por visitas de pessoas oriundas dos subúrbios com seus gostos de beber cerveja, de fazer churrasco e de tocar aos berros música funk e sertaneja.

Contudo, no espírito de Bourdieu, podemos citar Kahn (1989) que argumentou que a cultura criada no turismo é tão "autêntica" quanto aquela construída por um antropólogo (ou um geógrafo), inclusive, aos diferentes fenômenos culturais apresentados aqui por um velho antropólogo, com larga experiência na Geografia, que também é um turista veterano na área de estudo. $\mathrm{Na}$ apresentação das sucessivas relações socioambientais que se deram através do tempo na baia de Sepetiba, tentei controlar, ou pelo menos deixar transparentes, as "subjetividades", tanto do pesquisador quanto do turista sujeito do estudo. Podemos concluir: se a "objetividade" na pesquisa social é impossível, podemos tentar mirar a "objetivação participante".

Agradecimentos

Pesquisa apoiada pelo Conselho Nacional de Desenvolvimento Científico e Tecnológico (CNPq) e pela Fundação Carlos Chagas Filho de Amparo à Pesquisa do Estado do Rio de Janeiro (FAPERJ).

Submetido em 14 de março de 2018.

Aceito para publicação em 15 de agosto de 2018. 
Referências

ANDERSON, R. Anthropology of fishing. Annual Review of Anthropology vol. 10, p. 275-316, 1981.

ANDERSON, R.; WADEL, G. (orgs.). North Atlantic Fishermen. St. John's: Memorial University of Newfoundland, 1972.

BECKEN, S.; HAY, G. E. Tourism and Climate Change. Clevedon: Frankfurt Lodge, 2007.

BIASOTTO, R. Territorialidade dos Pescadores de Itaipu. Dissertação de mestrado, Programa de Pós-Graduação em Geografia, UFRJ, Rio de Janeiro, 1995.

BLAIKIE, P.; BROOKFIELD, H. Land Degradation and Society. London: Metheun, 1987.

BARADÓ, M. Siderúrgica TKCSA é o novo matadouro de Santa Cruz, no Rio de Janeiro. http://psolriodasostras.wordpress.com/2011/03/12/siderurgica-tkcsa-e-o-novo-matadouro-desanta-cruz-no-rio-de-janeiro, 2011.

BOURDIEU, P. An Outline to a Theory of Practice. Cambridge: Cambridge Univ. Press, 1978(1972).

Homo academicus. Florianópolis: UFSC, 2011(1988).

Participant objectivation. Journal of the Royal Anthropological Institute vol. 9, no. 2, p. 281-294, 2003.

BRYANT, C.; JOHNSTON, T. Agriculture in the City's Countryside. London: Belhaven, 1992.

BUCKLEY, R. C. (org.). Environmental Impacts of Ecotourism. Wallingford: CABI, 2008.

BÜSCHER, B.; FLETCHER, R. Under pressure: conceptualising political ecologies of green wars. Conservation and Society AOP, p. 1-9, 2018.

CATER, C.; CATER, E. Marine Ecotourism. Wallingford: CABI, 2007.

CLIFT, S.; CARTER, S. (orgs.). Tourism and Sex. London: Pinter, 2000.

CLOKE, P.; COOK, I.; CRANG, P.; GOODWIN, M.; PAINTER, J.; PHILO, C. Practising Human Geography. London: Sage, 2004.

COLE, S. Women of the Praia. Princeton: Princeton Univ. Press, 1991.

COSGROVE, D. Commentary. Annals of the American Association of Geographers vol. 83, p. 515-517, 1993.

CRESSWELL, T. Geographic Thought. Chichester: Wiley-Blackwell, 2013.

CROSBY, A. Ecological Imperialism. Cambridge: Cambridge Univ. Press, 1986.

DIEGUES, A.C. Pescadores, Camponeses e Trabalhadores do Mar. São Paulo: Ática, 1983. Ecologia Humana e Planejamento Costeiro. São Paulo: HUCITEC, 1991. . O Mito da Natureza Intocada. São Paulo: HUCITEC, 1996. 
DOWIE, M. Conservation Refugees: the Hundred-year Conflict between Global Conservation and Native Peoples. Cambridge: MIT Press, 2009.

EAGLES, P. F. J.; McCOOL, S. F. Tourism in National Parks and Protected Areas. Wallingford: $\mathrm{CABI}, 2000$.

FENNELL, D. A. Tourism and Animal Ethics. Milton Park: Routledge, 2011.

FIOCRUZ. 2010. Estudo aponta principais setores poluidores da Baía de Sepetiba. Informe ENSP p.1-2. www. fiocruz.br/ccs/cgi/cgilua.exe/sys/start.htm?infoid=3352\&sid=9\&tpl= printerview

FORSYTH, T. Critical Political Ecology: The Politics of Environmental Science. Milton Park: Routledge, 2003. . Industrial pollution and social movements in Thailand. In, PEET, R.; WATTS, M. (orgs.) Liberation Ecology. $2^{\mathrm{a}}$ edição. London: Routledge, 2004, p. 422-438.

FRIDMAN, F. Três vilas da província fluminense. Estudos de História vol. 8, no. 2, p. 1-13, 2001.

GARLAND, E. How should anthropologists be thinking about volunteer tourism? Practicing Anthropology vol. 34, no. 3, p. 5-9, 2012.

GOODMAN, D.; REDCLIFT, M. From Peasant to Proletarian. Oxford: Blackwell, 1981.

GOODMAN, J.; SILVERSTEIN, P. A. Bourdieu in Algeria: Colonial Politics, Ethnographic Practices, Theoretical Development. Lincoln: Univ. of Nebraska Press, 2009.

GREENLAW, L. The Hungry Ocean. New York: Hyperion, 1999.

GUIMARÃES, E. Impacto da Urbanização sobre Comunidades Pesqueiras Artesanatos do Município de Maricá - RJ. Dissertação de mestrado, Programa de Pós Graduação em Geografia, UFRJ, Rio de Janeiro, 1987.

HOEFLE, S. W. Fishing, tourism and industrial development in Southeast Brazil. In, AGUERO, M. (org.). Contribuciones al Estudio de la Pesca en America Latina. Manila: ICLARM, 1992, p. $70-91$.

. Colonialismo carbônico na Amazônia? Espaço Aberto 3(2): 109-130, 2013.

. Ghosts in the forest: the moral ecology of environmental governance toward poor farmers in the Brazilian and US Atlantic Forests. In, GRIFFIN, C., JONES, R. e ROBERTSON, I. (orgs.), Moral Ecologies: Histories of Conservation, Dispossession and Resistance. London: Palgrave Macmillan (no prelo).

HOEFLE, S. W.; BICALHO, A. M. S. M. Nature enclosures: historic peasants versus public and private conservation units of the Paraguay River in the Pantanal wetlands of western Brazil. BelGeo vol. 4, p. 1-18, 2016.

HUBER, M. T. Industrializing political ecology. Annals of the American Association of Geographers vol. 107, no. 1, p. 151-166, 2017.

IBGE (Instituto Brasileiro de Geografia e Estatística). Censo Demográfico. Rio de Janeiro, 1980, 2010. 
INGLES, P. Anthropology and fisheries management in the United States: methodology for research special issue. Annals of Anthropological Practice vol. 28, p. 1-166, 2007.

JACOBY, K. Crimes against Nature: Squatters, Poachers, Thieves. $2^{a}$ edição. Berkeley: University of California Press, 2014.

de KADT, E. The issues addressed. In, de KADT, E. (org.) Tourism: Passport to Development? New York: Oxford University Press, 1979, p. 3-76.

KAHN, J. Culture: demise and resurrection? Critique of Anthropology vol. 9, p. 5-25, 1989.

KELLY-RAIF, K.; WING, S. Urban-rural exploitation: an underappreciated dimension of environmental injustice. Journal of Rural Studies vol. 47, no. 4, p. 350-358, 2016.

KOTTAK, C. Assault on Paradise. New York: Random House, 1983.

. The globalization of a Brazilian fishing community. General Anthropology vol. 16, no. 1, p. 5-7, 2009.

KUHN, T. The Structure of Scientific Revolutions. Chicago: University of Chicago Press, 1962.

LÉVI-STRAUSS, C. The Savage Mind. Chicago: University of Chicago Press, 1969(1962).

LIMA, P. A Atividade Pesqueira em Arraial do Cabo. Dissertação de mestrado, Programa de Pós-Graduação em Geografia, UFRJ, Rio de Janeiro, 1993.

MANSFIELD, B. 'Modern' industrial fisheries and the crisis of overfishing. In, PEET, R.; ROBBINS, P.; WATTS, M. (orgs.). Global Political Ecology. London: Routledge, 2011, p. 84-99.

MARCUS, G. Ethnography in/of the world system: the emergence of multi-sited ethnography. Annual Review of Anthropology vol. 24, p. 95-117, 1995.

McCAY, B. J. Anthropology: shifts in fishing grounds. Nature Climate Change vol. 2, p. 849-851, 2012.

McGOODWIN, J. R. Crisis in the World's Fisheries. Stanford: Stanford University Press, 1990.

MENDRAS, H. Sociedades Camponesas. Rio de Janeiro: Zahar, 1978(1976).

MERCHANT, C. Radical Ecology. London: Routledge, 1992.

NICE, R. Translator's Forward. In, BOURDIEU, P., Outline of a Theory of Practice. Cambridge: Cambridge Univ. Press, 1978, p. vii-viii.

NYMAN, E. Island exceptionalism and international maritime conflicts. Professional Geographer vol. 65, p. 221-229, 2013.

PAULSON, S.; GERZON, L. L.; WATTS, M. Locating the political in political ecology. Human Organization vol. 62, p. 205-217, 2003.

PEET, R.; ROBBINS, P; WATTS, M. (orgs.). Global Political Ecology. London: Routledge, 2011, p. 84-99.

PEET, R.; WATTS, M. Liberation ecology. In, PEET, R.; WATTS, M. (orgs.). Liberation Ecology. 2a edição. London: Routledge, 2004, p. 1-45.

PEARCE, D. Tourist Development. London: Longman, 1981. 
PEREIRA, J. V. C. Salinas. In, IBGE (org.) Tipos e Aspectos do Brasil. Rio de Janeiro, IBGE, 1949, p. 194-199.

PIERCE, D. G.; BUTLER, R. W. (orgs.). Tourism Research. London: Routledge, 1993.

PRITCHARD, A.; N. MORGAN, N.; ATELJEVIC, N.; HARRIS, C. (orgs.). Tourism and Gender. Wallingford: CABI, 2007.

RADEMACHER, A. Urban political ecology. Reviews of Anthropology vol. 44, p. 137-152, 2015.

RAKIC, T.; CHAMBERS, D. (orgs.). An Introduction to Visual Research Methods in Tourism. Milton Park: Routledge, 2011.

REDCLIFT, M. Development and the Environmental Crisis: Red or Green Alternatives? London: Metheun, 1984.

Sustainable Development: Exploring the Contradictions. London: Routledge, 1987.

RICHARDS, G.; MUNSTERS, W. (orgs.). Cultural Tourism Research Methods. Wallingford: CABI, 2010.

RITCHIE, B. W.; BURNS, P.; PALMER, C. (orgs.). Tourism Research Methods. Wallingford: CABI, 2005.

ROBINSON, G. Conflict and Change in the Countryside. London: Wiley, 1990.

RYAN, C.; HALL, C. M. Sex Tourism. London: Routledge, 2001.

SARTRE. J-P. Search for a Method. New York: Alfred A. Knoft, 1963(1957).

SCHULTHEIS, F. Picturing Algeria - Pierre Bourdieu's beginnings in ethnography and sociology. www.alexandria.unisp.ch/223288/1/130411\%Vortrag\%20FS\%, 2013.

SCOTT, D.; HALL, C. M.; GÖSSLING, S. Tourism and Climate Change. Milton Park: Routledge, 2012.

SPOEHR, A. Protein from the Sea. Pittsburg: Univ. of Pittsburg Press, 1980.

SMITH, M. E. (org.). Those Who Live from the Sea. St. Paul: West, 1977.

SMITH, S. L. J. Recreation Geography. London: Longman, 1983.

SMITH, V. L. Introduction. In, SMITH V. L. (org.) Hosts and Guests. Philadelphia: Univ. of Pennsylvania Press, 1977, p. 1-20.

STRONZA, A.; DURHAM, W. H. (orgs.). Ecotourism and Conservation in the Americas. Wallingford: CABI, 2008.

TAYLOR, M. The Political Ecology of Climatic Change Adaptation. London: Routledge/Earthscan, 2015.

URRY, J. The Tourist Gaze. London: Sage, 1990.

WAITT, G.; MARKWELL, K. Gay Tourism. Binghamton: Haworth, 2006.

WEARING, S. Volunteer Tourism. Wallingford: CABI, 2001.

WILSON, G., BARTON, R.J.F. 'Neo-productivist' agriculture: Spatio-temporal versus structuralist 
perspectives. Journal of Rural Studies vol. 38, p. 52-64, 2015.

WOLF, E. R. Sociedades Camponesas. Rio de Janeiro: Zahar, 1976(1966).

Europe and the Peoples without History. Berkeley: University of California Press, 1982.

WOODS, M. Rural. Milton Park: Routledge, 2012.

ZEPPEL, H. Indigenous Ecotourism. Wallingford: CABI, 2006.

ZULAIKA, J. Terranova. Philadelphia: ISHI, 1981. 